\title{
Oxygen minimum zone of the open Arabian Sea: variability of oxygen and nitrite from daily to decadal timescales
}

\author{
K. Banse ${ }^{1}$, S. W. A. Naqvi ${ }^{2}$, P. V. Narvekar ${ }^{2,}$, J. R. Postel ${ }^{1}$, and D. A. Jayakumar ${ }^{2, *}$ \\ ${ }^{1}$ University of Washington, School of Oceanography, Box 357940, Seattle, Washington 98195-7940, USA \\ ${ }^{2}$ National Institute of Oceanography, Council of Scientific \& Industrial Research, Dona Paula, Goa 403 004, India \\ *now at: Princeton University, M45 Guyot Hall, Department of Geosciences, Princeton, New Jersey 08544, USA \\ deceased
}

Correspondence to: K. Banse (banse@uw.edu)

Received: 15 August 2013 - Published in Biogeosciences Discuss.: 30 September 2013

Revised: 12 February 2014 - Accepted: 17 February 2014 - Published: 23 April 2014

\begin{abstract}
The oxygen minimum zone (OMZ) of the Arabian Sea is the thickest of the three oceanic OMZ. It is of global biogeochemical significance because of denitrification in the upper part leading to $\mathrm{N}_{2}$ and $\mathrm{N}_{2} \mathrm{O}$ production. The residence time of OMZ water is believed to be less than a decade. The upper few hundred meters of this zone are nearly anoxic but non-sulfidic and still support animal (metazoan) pelagic life, possibly as a result of episodic injections of $\mathrm{O}_{2}$ by physical processes.

We report on discrete measurements of dissolved $\mathrm{O}_{2}$ and $\mathrm{NO}_{2}^{-}$, temperature and salinity made between 1959 and 2004 well below the tops of the sharp pycnocline and oxycline near $150,200,300,400$, and $500 \mathrm{~m}$ depth. We assemble nearly all $\mathrm{O}_{2}$ determinations (originally there were 849 values, 695 of which came from the OMZ) by the visual endpoint detection of the iodometric Winkler procedure, which in our data base yields about $0.04 \mathrm{mLL}^{-1}(\sim 2 \mu \mathrm{M}) \mathrm{O}_{2}$ above the endpoint from modern automated titration methods. We acknowledge that much lower (nanomolar) $\mathrm{O}_{2}$ values have been measured recently with the STOX (Switchable Trace amount OXygen) sensor in the eastern tropical South Pacific, and that similar conditions may also prevail in the Arabian Sea OMZ. In spite of the error in $\mathrm{O}_{2}$ measurements at vanishingly low levels, we argue that the temporal trends of the historic data should still hold.

We find 632 values acceptable (480 from 150 stations in the OMZ). The data are grouped in zonally paired boxes of $1^{\circ}$ lat. and $2^{\circ}$ long. centered at $8,10,12,15,18,20$, and $21^{\circ} \mathrm{N}$ along 65 and $67^{\circ} \mathrm{E}$. The latitudes of $8-12^{\circ} \mathrm{N}$, outside the OMZ, are treated in passing. The principal results are
\end{abstract}

as follows: (1) an $\mathrm{O}_{2}$ climatology for the upper $\mathrm{OMZ}$ reveals a marked seasonality at 200 to $500 \mathrm{~m}$ depth with $\mathrm{O}_{2}$ levels during the northeast monsoon and spring intermonsoon seasons elevated over those during the southwest monsoon season (median difference, $0.08 \mathrm{mLL}^{-1}[\sim 3.5 \mu \mathrm{M}]$ ). The medians of the slopes of the seasonal regressions of $\mathrm{O}_{2}$ on year for each of the NE and $\mathrm{SW}$ monsoon seasons are -0.0043 and $-0.0019 \mathrm{mLL}^{-1} \mathrm{a}^{-1}$, respectively $(-0.19$ and $-0.08 \mathrm{MM} \mathrm{a}^{-1} ; n=10$ and 12 , differing at $p=0.01$ ); (2) four decades of statistically significant decreases of $\mathrm{O}_{2}$ between 15 and $20^{\circ} \mathrm{N}$ but an opposing trend toward an increase near $21^{\circ} \mathrm{N}$ are observed. The mechanisms of the balance that more or less annually maintain the $\mathrm{O}_{2}$ levels are still uncertain. At least between 300 and $500 \mathrm{~m}$, the replenishment is inferred to be due to isopycnal re-supply of $\mathrm{O}_{2}$, while at 200 (or 250 ?) $\mathrm{m}$ it is diapycnal, most likely by eddies. Similarly, recent models show large vertical advection of $\mathrm{O}_{2}$ well below the pycnoclines and oxyclines.

The $\mathrm{NO}_{2}^{-}$distribution, taken as an indicator of active $\mathrm{NO}_{3}^{-}$ reduction, does not show a trend in the redox environment for a quarter of a century at a GEOSECS station near $20^{\circ} \mathrm{N}$. In the entire $\mathrm{OMZ}$, the regression slopes on year within seasons for the rather variable $\mathrm{NO}_{2}^{-}$do not present a clear pattern but by other measures tended to an increase of $\mathrm{NO}_{2}^{-}$.

Vertical net hauls collect resident animal (metazoan) pelagic life in the $\mathrm{NO}_{2}^{-}$maximum of the $\mathrm{OMZ}$ at $\mathrm{O}_{2}$ levels well below the lower limit of the Winkler titration; the extremely low $\mathrm{O}_{2}$ content is inferred from the presence of $\mathrm{NO}_{2}^{-}$believed to be produced through microbial $\mathrm{NO}_{3}^{-}$reduction. Instead of the difficult measurement by the STOX 
sensor, the relation between the very low $\mathrm{O}_{2}$ inferred from presence of $\mathrm{NO}_{2}^{-}$and mesozooplankton should be studied with 100 to $150 \mathrm{~L}$ bottles rather than nets.

The spatial (within drift stations) and temporal (daily) variability in hydrography and chemistry is large also below the principal pycnocline. The seasonal change of hydrography is considerable even at $500 \mathrm{~m}$ depth. Future $\mathrm{O}_{2}$ or nutrient budgets for the OMZ must not be based on single cruises or sections obtained during one season only. Steady state cannot be assumed any longer for the intermediate layers of the central Arabian Sea.

\section{Introduction}

Our paper addresses variability and climatology of dissolved oxygen $\left(\mathrm{O}_{2}\right)$ and nitrite $\left(\mathrm{NO}_{2}^{-}\right)$from discrete samples collected between 1959 and 2004 in the upper oxygen minimum zone (OMZ) of the central Arabian Sea, which includes the secondary nitrite maximum (SNM). The entire OMZ occupies approximately the $150-1000 \mathrm{~m}$ depth range and is the thickest of the three major OMZs of the open ocean. Between one-fourth and one-third of the total marine denitrification is estimated to occur in the water column, of which up to one-third to one-half may take place within the OMZ of the Arabian Sea (Codispoti et al., 2001; Bange et al., 2005). According to Naqvi et al. (2005: Table 9), the contribution by the Arabian Sea to the global marine pelagic denitrification lies between 8 and $21 \%$. The principal denitrifying zone is located in the upper one-third of the $\mathrm{OMZ}$ where $\mathrm{O}_{2}$ concentrations, as determined by visual endpoint detection of the Winkler titration, fall below $0.06 \mathrm{mLL}^{-1}(\sim 2.7 \mu \mathrm{M}$; however, see below). The zone is readily identifiable by the SNM, which mostly is due to $\mathrm{NO}_{3}^{-}$reduction and separate from the primary $\mathrm{NO}_{2}^{-}$maximum that is more commonly found near the bottom of the euphotic zone (cf. Supplement Fig. S.3.1; Lomas and Lipschultz, 2006). Other than the release of $\mathrm{N}_{2}$ as the end product through denitrification and anammox pathways (Dalsgaard et al., 2003, 2005; Kuypers et al., 2003; Ward et al., 2009; Ward, 2013), the $\mathrm{O}_{2}$ deficiency enhances the production of nitrous oxide $\left(\mathrm{N}_{2} \mathrm{O}\right)$, a greenhouse gas, another intermediate of the nitrogen redox chemistry (Naqvi and Noronha, 1991; Devol et al., 2006; Naqvi et al., 2006).

The OMZ is not restricted to a particular range of temperature, salinity, or density and is essentially maintained by the balance between the supply of $\mathrm{O}_{2}$ through eddy mixing and horizontal advection, principally from the southwest, and local consumption. The mean residence time of water appears to be about a decade or less, according to Naqvi (1987, $\sim 4$ years, for 100 to $1000 \mathrm{~m}$ ) and Olson et al. (1993: 679; 11 years for 200 to $1000 \mathrm{~m}$ ). In contrast, Lam et al. (2011) estimated a $\mathrm{NO}_{2}^{-}$turnover time of $49 \pm 20$ years for 100 to $1000 \mathrm{~m}$ depth in the central-northeastern Arabian Sea. They divided the $\mathrm{NO}_{2}^{-}$inventory by the modeled $\mathrm{NO}_{2}^{-}$net pro- duction rate. We are concerned, however, with the depths $<500 \mathrm{~m}$. Therefore, one would divide a slightly lower inventory by the substantial, measured $\mathrm{NO}_{3}^{-}$reduction rate (Lam et al., 2011, upper Fig. 3d), which will reduce the turnover $=$ residence time greatly. The estimates of neither Naqvi (1987) nor Olson et al. (1993) lend themselves to correction. Further, Warren (1994) has remarked on the basic weakness of simple box models such as these. Incidentally, note that residence time of water is not the same as the age of water estimated by, for example, freon (CFC-11 or 12). So, accepting a short residence time, temporal $\mathrm{O}_{2}$ changes should be discernible in historical data from four decades as analyzed here. Because small $\mathrm{O}_{2}$ shifts at the generally quite low concentrations in the OMZ may suddenly stop or start denitrification, the temporal variability of the intensity and geographical extent of this OMZ are of global biogeochemical significance.

After we had largely completed our analysis of the historical $\mathrm{O}_{2}$ data, we learned of the introduction to the field of the STOX sensor (Switchable Trace amount OXygen; Revsbech et al., 2009). Its detection limit is almost two orders of magnitude lower than that of the automated Winkler titration and will necessitate a re-assessment of the intensity of the oceans' OMZs. Titration was hitherto used worldwide for $\mathrm{O}_{2}$ studies, as well as for the calibration of the $\mathrm{O}_{2}$ probes attached to CTDs. Thamdrup et al. (2012) in February 2007 employed the sensor along a section from 28 to $5^{\circ} \mathrm{S}$ off the continental slope in the eastern tropical South Pacific (ETSP). In the OMZ core between about 100 and 300-350 m depth, $\mathrm{O}_{2}$ was consistently undetectable on 10 of 12 stations (detection limit $0.01 \mu \mathrm{mol} \mathrm{kg}{ }^{-1}$ or less). The authors found depletion to $<0.09 \mu \mathrm{mol} \mathrm{kg}^{-1} \mathrm{O}_{2}\left(\sim 0.002 \mathrm{mLL}^{-1}\right)$ to be normal in the core. Further, $\mathrm{NO}_{2}^{-}$in the SNM occurred only at $<0.05 \mu \mathrm{mol} \mathrm{kg} \mathrm{O}_{2}\left(\sim 0.001 \mathrm{~mL} \mathrm{~L}^{-1}\right)$, which is lower by at least an order of magnitude than the best automated endpoint detection of the Winkler titration or the colorimetric measurements (Codispoti et al., 2001). Thamdrup et al. (2012) concluded that the core of the OMZ off Peru is broadly functionally anoxic, because the observed low $\mathrm{O}_{2}$ cannot sustain aerobic metabolism for any lengthy period. Ulloa et al. (2012) applied the term AMZ (Anoxic Marine Zone) to the region. The offshore OMZ of the ETSP, however, is non-sulfidic, because $\mathrm{NO}_{3}^{-}$is broadly present (Silva et al., 2009; Thamdrup et al., 2012). Since metazoans like copepods are obligatory aerobes, we consider AMZ to mean a water column without animal zooplankton on a $24 \mathrm{~h}$ basis and use the term accordingly.

Because of the many samples with high concentrations of $\mathrm{NO}_{2}^{-}$, the OMZ of the Arabian Sea is expected to broadly present low oxygen conditions similar to those in the ETSP. We know of only one instance, though, when $\mathrm{O}_{2}$ was measured using STOX in the region (September/October 2007, in Jensen et al., 2011: Supplement Fig. S.2). On three stations over depth intervals of several hundred meters, dissolved $\mathrm{O}_{2}$ 
was $\leq 0.09 \mu \mathrm{mol} \mathrm{kg}{ }^{-1}\left(\sim 0.002 \mathrm{mLL}^{-1}\right)$, which was the detection limit of the sensor on the cruise. $\mathrm{NO}_{3}^{-}$has always been found in fairly high concentrations in every sample analyzed within the OMZ during the last five decades, however, ruling out sulfidic anoxia in the water column. Also, metazoan plankton is present throughout, albeit in diminished numbers within the upper OMZ (Sect. 3.2.5).

The $\mathrm{OMZ}$ and the deep $\mathrm{NO}_{2}^{-}$maximum it contains were first discovered in 1933/1934 by Gilson (1937). Numerous $\mathrm{NO}_{2}^{-}$measurements during many subsequent expeditions in the Arabian Sea showed values $>0.5 \mu \mathrm{M}$ and up to $\sim 5 \mu \mathrm{M}$, that commonly occur in our data as well. They imply that at least during the last 75 years, the lowest $\mathrm{O}_{2}$ concentrations in this OMZ must have been at nanomolar levels (Thamdrup et al., 2012), in contrast to all historical $\mathrm{O}_{2}$ data including those used herein (Supplement Table S.1.b). The appreciable nitrate deficit resulting from the partial denitrification and anammox, ranging at its vertical maximum between 2 and $15 \mu \mathrm{MNO}_{3}^{-}$, has been discussed since the mid-1970s (e.g., Sen Gupta et al., 1976; see also Sect. 3.2.6). The OMZ has existed during much of the Holocene, as apparent from the sedimentary record spanning many thousands of years with uninterrupted series of annual varves at two sites located in the northeastern Arabian Sea (von Rad et al., 1999; Staubwasser et al., 2002; Thamban et al., 2007).

So, today, is the OMZ of the Arabian Sea, or at least its core, functionally anoxic as suggested by Thamdrup et al. (2012) and Ulloa et al. (2012) for the core of the OMZ of the eastern tropical South Pacific? The answer is No. The OMZ of the Arabian Sea as a whole is not a nonsulfidic anoxic marine zone (AMZ) as envisaged by Ulloa et al. (2012) and Thamdrup et al. (2012). Metazoan (animal) zooplankton reside in the $\mathrm{OMZ}$ even where the median $\mathrm{O}_{2}$ content, as determined by the Winkler procedure, is lowest (Sect. 3.2.5). Further, we will show by the 40 year climatology in our wide longitudinal swath (Fig. 1) that the upper 200 (or 250?) $\mathrm{m}$ are seasonally being stirred, presumably by eddies. In contrast, at the 300 to $500 \mathrm{~m}$ horizons $\mathrm{O}_{2}$ apparently is advected annually along isopycnals and replenishes the $\mathrm{O}_{2}$ consumed during the SWM period (Sect. 4.2.1). Moreover, $\mathrm{NO}_{2}^{-}$is largely observed only in the upper part of the OMZ, generally between 150 and $400 \mathrm{~m}$ depth, although the lower boundary of the SNM could sometimes be as deep as $600-700 \mathrm{~m}$ in the northeastern Arabian Sea (Naqvi, 1987; Morrison et al., 1999). Importantly, in our data sets between 200 and $500 \mathrm{~m}, 21 \%$ of 707 samples of boxes D1-G2 (without $500 \mathrm{~m}$ in D1, D2, see Table 2) contained zero to $\leq 0.02 \mu \mathrm{M} \mathrm{NO}_{2}^{-}$(Sect. 3.2.5). Thus, there was enough $\mathrm{O}_{2}$ present to prevent the onset of denitrification. In contrast, this percentage was $82 \%$ of 255 samples outside the OMZ in boxes $\mathrm{A} 1-\mathrm{C} 2$ and the deepest horizon in the D-boxes. We also observed that about four-fifths of our 707 samples coming from the 200 to $500 \mathrm{~m}$ horizons, which have significant amounts of $\mathrm{NO}_{2}^{-}$, are unevenly distributed in space, as is the $>$ one-fifth that contains too much $\mathrm{O}_{2}$ to allow denitrifica-

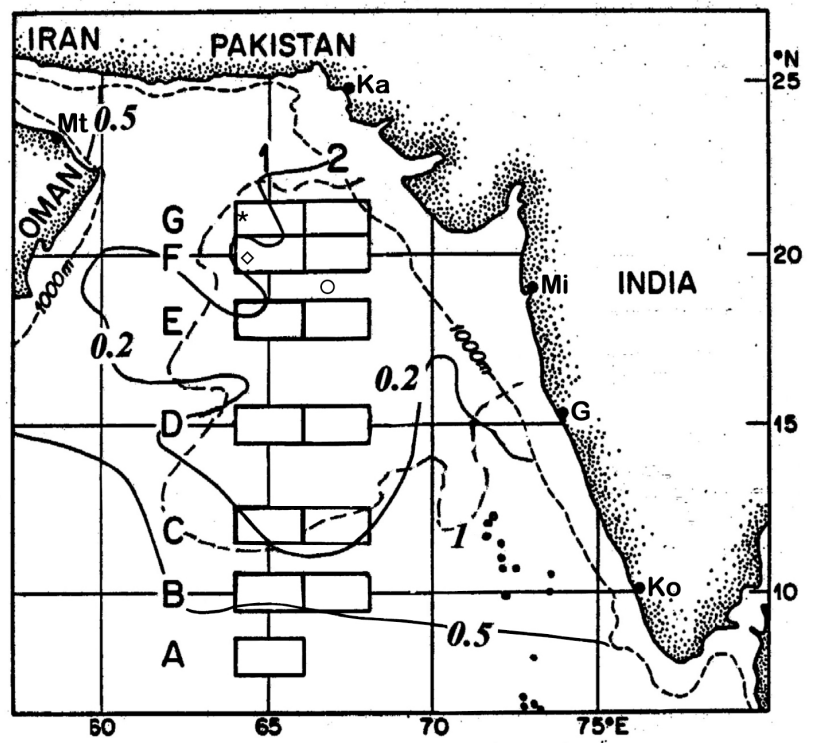

Fig. 1. Distribution of the boxes (left series, "1", right series, "2") with outlines of $\mathrm{O}_{2}$ concentration $\left(\mathrm{mL} \mathrm{L}^{-1}\right)$ at $200 \mathrm{~m}$ (from Wyrtki, 1971 ) and the nitrite maximum (circumscribed by the $1 \mu \mathrm{M}$ contour) in the OMZ (from Naqvi, 1991). Circle: position of drift station shown in Fig. 2; diamond: position of GEOSECS sta. 416; asterisk: position of drift station depicted in Supplement Fig. S.3.1; G: Goa; Ka: Karachi; Ko: Kochi (former Cochin); Mi: Mumbai (former Bombay); Mt: Muscat.

tion. Advection adds $\mathrm{O}_{2}$ at least occasionally to OMZs and AMZs also off Peru, as noted by Thamdrup et al. (2012) and off northern Chile as illustrated by Ulloa et al. (2012) for June 2007.

As shown in Supplement Sect. 2, the detection limit of the titration endpoint in our data collation is $\sim 0.04 \mathrm{~mL} \mathrm{~L}^{-1} \mathrm{O}_{2}$ $(\sim 2 \mu \mathrm{M})$ above the endpoint of modern automated methods $\left(\sim 0.01 \mathrm{mLL}^{-1} \mathrm{O}_{2}[\sim 0.4 \mu \mathrm{M}]\right)$. However, in spite of the uncertainties in the determination of $\mathrm{O}_{2}$ at vanishingly small concentrations, we believe that the temporal trends reported herein remain valid. Were it not so, the ocean- and basinscale sections of low dissolved $\mathrm{O}_{2}$ currently in the literature would not closely reflect the basin-wide distribution of nutrients.

Below, we describe first the methods and data selection for temperature, salinity, oxygen, and nitrite in subsamples drawn from the same water bottle. Then we review and update the setting of the OMZ to $500 \mathrm{~m}$ depth, including the small-scale spatial and temporal (days to weeks) variability in order to provide perspective on the observations. The core of the paper addresses seasonal and four-decadal changes of $\mathrm{O}_{2}$ and $\mathrm{NO}_{2}^{-}$. We conclude with a section on the implications of the results. 


\section{Materials and methods}

\subsection{Data sources}

The principal sources for our discrete observations of $\mathrm{O}_{2}$ and $\mathrm{NO}_{2}^{-}$together with temperature and salinity were the Indian and US national oceanographic data centers (INODC and NODC, respectively). Collections on some additional cruises conducted by India's National Institute of Oceanography but not yet incorporated in the INODC and NODC bases were also utilized. All data had been taken near 150, 200, 300, 400 , and $500 \mathrm{~m}$, within boxes of $1^{\circ}$ lat. by $2^{\circ}$ long. The boxes are centered at $8,10,12,15,18,20$, and $21^{\circ} \mathrm{N}$ along 65 and $67^{\circ} \mathrm{E}$ (from $\mathrm{A} 1$ to $\mathrm{G} 1$ and $\mathrm{B} 2$ to $\mathrm{G} 2$, respectively, in Fig. 1). While the text and the figures refer to rounded nominal depths, the great majority of our data were collected within $5 \%$ and in some cases within $10 \%$ of the nominal horizons. In addition, we include some $\mathrm{O}_{2}$ observations at exact nominal depths and the very few values from data centers that were already interpolated to them. The measurements used are listed in Supplement Table S.1.b together with the temperature and salinity of the samples.

We identify the seasons following the US Joint Global Ocean Flux Study (JGOFS) classification (Morrison et al., 1998) but the starting dates lagged by a half a month to one month: northeast monsoon (NEM), DecemberMarch; spring intermonsoon (SI), April-May; southwest monsoon (SWM), June-September; and fall intermonsoon (FI), October-November. The lag is introduced because the biochemical response at depth depends also on the downward transmission of surface signals by sinking particles.

\subsection{Temperature and salinity}

All temperatures and salinities accompanying the $\mathrm{O}_{2}$ and/or $\mathrm{NO}_{2}^{-}$data were taken at face value except that five hydrographic series (including the $\mathrm{O}_{2}$ and $\mathrm{NO}_{2}^{-}$values) were eliminated as occurring in exceptionally deep eddies (two series) or as clearly due to pre-trips of the entire bottle strings. A very few salinity records were dropped as false by being obvious outliers in $T-S$ diagrams. To fill in large temporal gaps, a few measurements without $\mathrm{O}_{2}$ and/or $\mathrm{NO}_{2}^{-}$observations were taken from the data centers. Data from 329 and 332 stations with 1376 temperature and 1380 salinity values, respectively, were utilized (Supplement Table S.1.b). As in the case of $\mathrm{O}_{2}$ and $\mathrm{NO}_{2}^{-}$, the total includes some means of replicate casts at routine or drift stations. Supplement Tables S.2 and S.3 present the medians of temperature and salinity for all boxes and depths.

\subsection{Oxygen}

This section treats analytical bias, as well as describes our criteria for rejecting many reported values.

Our $\mathrm{O}_{2}$ data were generated by the iodometric Winkler titration technique with visual end point detection (see Sup- plement Sect. S.2). This procedure was in general use until it was partially replaced by automated titration, by which also the CTD-attached $\mathrm{O}_{2}$ probes were calibrated. For our boxes we strove to collect all observations based on manual Winkler titrations with visual endpoint detection, but had to remove quite a few because of obvious bias as detailed below. Measurements by other methods, i.e., those involving automated (e.g., colorimetric or photometric) endpoint detection of the iodometric titration, were not considered, unless noted, because of systematic differences in the analytical results discussed below. Excluded thus are cruises 118 and 159 of R/V Gaveshani, as well as the observations from cruises 99 and 104 of R/V Sagar Kanya and all those by R/V T. G. Thompson and other recent expeditions. To our knowledge, for avoiding interference by nitrite, sodium azide was not added on any expedition except those by R/V T. G. Thompson (Morrison et al., 1999).

Almost all of our $\mathrm{O}_{2}$ data were recorded in $\mathrm{mLL}^{-1}$, which we did not convert to $\mu \mathrm{M}$ or $\mu \mathrm{mol} \mathrm{kg}{ }^{-1}$, except for means and medians, because reporting the exact multiplication would have added a decimal place implying a false precision, whereas rounding off might have introduced errors in means and medians of sets of often only five to ten values. Original observations expressed as $\mu \mathrm{mol} \mathrm{kg}{ }^{-1}$ were retained but also stated as converted $v / v$ or molar units.

During the last two to three decades $\mathrm{O}_{2}$ was analyzed with automated endpoint detection in the Winkler analysis (JGOFS manual; Anon., 1994). By comparing such measurements with visual endpoint detection in the same boxes during the same periods, we find an overestimate by $0.04 \mathrm{mLL}^{-1} \mathrm{O}_{2}(\sim 2 \mu \mathrm{M})$ (Supplement Sect. 2). Without further evidence we generalize the difference as applicable to our entire material in Supplement Table S.1.b. In view of the low $\mathrm{O}_{2}$ concentrations in the OMZ (Sect. 3.1.2), the bias is far from negligible.

The accuracy in historical $\mathrm{O}_{2}$ data may vary for a number of reasons. For quality control we used the accompanying $\mathrm{NO}_{2}^{-}$values, all accepted at face value, and eliminated $\mathrm{O}_{2}$ values $>0.10 \mathrm{mLL}^{-1}$ when they were accompanied by $\mathrm{NO}_{2}^{-}$values $>0.2 \mu \mathrm{M}$. As stated above, high $\mathrm{NO}_{2}^{-}$is an indicator of denitrification, and if associated with substantial $\mathrm{O}_{2}$ it implies overestimation of the latter (see Sect. 1; also Supplement Sect. 2). We corrected apparent $\mathrm{O}_{2}$ measurements $<0.10 \mathrm{~mL} \mathrm{~L}^{-1}$ accompanied by $\mathrm{NO}_{2}^{-} \geq 0.2 \mu \mathrm{M}$ for nitrite interference (Wong, 2012) and signified these by italics in Supplement Table S.1.b. Our cutoff of $0.2 \mu \mathrm{MNO}_{2}^{-}$for eliminating $\mathrm{O}_{2}>0.10 \mathrm{mLL}^{-1}$ was rather subjective but seemed justifiable given the variability in $\mathrm{NO}_{2}^{-}$blanks that may introduce errors up to $\sim 0.05 \mu \mathrm{M}$. Of course, in view of the recently recognized much lower $\mathrm{O}_{2}$ threshold for the onset of denitrification (Sect. 1), the cutoff is indeed arbitrary and only serves to sort our data collation. The $1 \mu \mathrm{M}$ contour in our Fig. 1 is close to the $0.2 \mu \mathrm{M}$ contour in Naqvi (1991) demarcating the boundaries of the suboxic zone. 
From all boxes between about 150 and $500 \mathrm{~m}, 849 \mathrm{O}_{2}$ values based on visual endpoint detection from 205 stations were found (duplicate casts on the same station are averaged and not counted as such; also not included are rejected data from three cruises mentioned below). In the OMZ (boxes D1-G2), 695 observations or means were recorded. Of these, 215 values with $\mathrm{O}_{2}>0.10 \mathrm{~mL} \mathrm{~L}^{-1}$ accompanied by $\mathrm{NO}_{2}^{-} \geq 0.2 \mu \mathrm{M}$ were rejected. The remaining 480 data points came from 150 stations. Included are 31 stations with 56 samples with $\mathrm{O}_{2}>0.10 \mathrm{mLL}^{-1}$ not accompanied by $\mathrm{NO}_{2}^{-}$ analyses because there was no reason to reject them (of these, 14 came from $\sim 150 \mathrm{~m}$ where higher $\mathrm{O}_{2}$ values can be expected because of the proximity to the oxycline). The inclusion of the 56 points did not alter our conclusions except possibly the decadal slope at $400 \mathrm{~m}$ in F1 in 1963.

Rejected and not included in any of the enumerations were $\mathrm{O}_{2}$ records from two cruises that were in their entirety far too high within the $\mathrm{OMZ}$ north of 14 to $15^{\circ} \mathrm{N}$ during the four decades under consideration (R/V Priliv, May 1967; R/V Akademik Kurchatov, May 1976), as well as those from the 22nd cruise of R/V Akademik Vernadsky of 1980. Here, all $\mathrm{O}_{2}$ values $>0.10 \mathrm{mLL}^{-1}$ from the $\mathrm{OMZ}$ were accompanied by $\mathrm{NO}_{2}^{-}>0.2 \mu \mathrm{M}$, suggesting similar overestimates for the remaining determinations. Also dropped at the outset were several single $\mathrm{O}_{2}$ values from other expeditions that appeared unreasonably high from the context (e.g., as compared to values from adjoining depths, or which came from transition layers with strong gradients).

The totals are 632 accepted measurements from 196 stations between 8 and $21^{\circ} \mathrm{N}$ (Supplement Table S.1.b). Table 1 presents the numbers and medians of these $\mathrm{O}_{2}$ values for all boxes and depths.

\subsection{Nitrite}

Because the $\mathrm{O}_{2}$ values within the $\mathrm{OMZ}$ are often very close to the lower limit of detection and hence perhaps not as precise as is desirable, we use $\mathrm{NO}_{2}^{-}$as a surrogate of nearabsence of $\mathrm{O}_{2}$. On all cruises nitrite was determined following Bendschneider and Robinson (1952) or variants thereof. In contrast to the $\mathrm{O}_{2}$ observations, the data from the US Joint Global Ocean Flux Study (JGOFS) and World Ocean Circulation Experiment (WOCE) programs were also included in our study. For the five horizons under consideration, 1191 data points from 292 stations (949 from 227 stations in the OMZ) were utilized, all analyses having been taken at face value (Supplement Table S.1.b). These totals comprise some averages of two or three replicate casts per station, as well as means of $\geq 4$ (up to 28) replicated casts within the same day or consecutive days at fixed positions. Most of the high $\mathrm{NO}_{2}^{-}$ values were $<5 \mu \mathrm{M}$ except a few that exceeded this concentration (maximum $6.2 \mu \mathrm{M}$ ). One outlier of $10.2 \mu \mathrm{M}$ is found at $200 \mathrm{~m}$ in Box E2 in July 1970. Table 2 presents the numbers of samples and the medians for all boxes and depths.

\subsection{Statistics}

Seasonal and decadal changes were investigated by linear regression analysis with the independent variable (dates, i.e., year and month) known, and parametric statistics without testing for normality and homoscedasticity. Significance of differences between medians or groups of data was assessed by the non-parametric rank test (Wilcoxon $T$ test $=$ MannWhitney $U$ test). Because the latter mostly addressed clear differences between two data sets, one-tailed tests were usually applied. In neither approach did the values weight the statistics that were based on means. Our statements about significance of "differences between medians" are shorthand for "tests for significance of differences between two sets of independent values." The $p$ values reflect the distribution of the variables tested, but also the often low number of samples. Because so many sets are small, reporting even $p=0.2$ seems appropriate, but is not intended to serve as proof.

\section{Results and Discussion}

\subsection{Broad setting}

The area of study lies, strictly speaking, between 7.5 and $21.5^{\circ} \mathrm{N}$ and 64 to $68^{\circ} \mathrm{E}$ (Fig. 1), but the southern boxes (A$\mathrm{C}, 8-12^{\circ} \mathrm{N}$ ), which are outside the suboxic OMZ, are treated only in passing. Sketching the general setting of the Arabian Sea, we note that previously the two monsoons were thought to force reversal of surface currents seasonally over the entire basin. Actually, much of the western half of the Arabian Sea is full of cyclonic and anticyclonic, quasi-geostrophic mesoscale eddies and fronts with their associated meandering currents (Flagg and Kim, 1998; Shankar et al., 2002; Artamonov, 2006; Resplandy et al., 2011). The new insight is illustrated by maps of sea level anomalies (SLAs; Kim et al., 2001), sea surface height (Fischer et al., 2002; Weller et al., 2002; Resplandy et al., 2011), and geopotential anomalies (Artamonov, 2006). The eddies and fronts may reach $500 \mathrm{~m}$ depth (e.g., Artamonov, 2006: Figs. 3.15C-F, 3.16B; Bobko and Rodionova, 2006: $\mathrm{O}_{2}$ at $300 \mathrm{~m}$ in Fig. 5.6, $\mathrm{NO}_{3}^{-}$section in Fig. 5.8B). In addition, the salinity and temperature (CTD) profiles at stations in the northern boxes down to $\sigma_{\mathrm{t}}$ near $26 \mathrm{~kg} \mathrm{~m}^{-3}$ (roughly $200 \mathrm{~m}$ depth) show many salinity spikes in the pycnocline (see Figs. 2 and 8) from interweaving of relatively thin layers of varying salinity, presumably with varying biochemical histories. The cause probably is dense water from winter convection subducted and advected horizontally, then preserved in the pycnocline (e.g., Banse and Postel, 2009). Between $\sigma_{\mathrm{t}}$ of about $26-27 \mathrm{~kg} \mathrm{~m}^{-3}$, similar layering is due to the intrusion from the Persian Gulf (the Persian Gulf Water, PGW, see Supplement Sect. S.3). The overall result of, especially, the hydrographic processes is substantial variability even within stations replicated during one to three days (Sect. 3.2.4) and is superimposed over 
Table 1. Median $\mathrm{O}_{2}$ concentrations $\left(\mathrm{mLL}^{-1}\right)$ for all boxes near the indicated depths (number of values in parentheses; data in Table $\mathrm{S} .1 . \mathrm{b}$ ). One-sided $p$ for $\mathrm{O}_{2}$ difference between adjoining medians: $\left.* \leq 0.20 ; * \leq 0.10 ; * * \leq 0.05\right)$; blank, non-significant. ${ }^{1}$

\begin{tabular}{|c|c|c|c|c|c|c|c|c|c|}
\hline Box & $150 \mathrm{~m}$ & & $200 \mathrm{~m}$ & & $300 \mathrm{~m}$ & & $400 \mathrm{~m}$ & & $500 \mathrm{~m}$ \\
\hline $\mathrm{A} 1+\mathrm{A} 2$ & $\begin{array}{c}0.77(3) \\
* * *\end{array}$ & & $\begin{array}{c}0.99(5) \\
* * *\end{array}$ & & $\begin{array}{c}1.21(4) \\
* *\end{array}$ & & $0.92(1)$ & & $\begin{array}{c}0.96(4) \\
* *\end{array}$ \\
\hline B1 & $0.24(8)$ & $*$ & $\begin{array}{c}0.30(13) \\
*\end{array}$ & $* * *$ & $\begin{array}{c}0.72(7) \\
* *\end{array}$ & & $\begin{array}{c}0.68(8) \\
* *\end{array}$ & $* *$ & $\begin{array}{c}0.48(9) \\
* * *\end{array}$ \\
\hline $\mathrm{C} 1$ & $0.39(2)$ & & $\begin{array}{c}0.27(6) \\
* *\end{array}$ & & $0.36(3)$ & & $\begin{array}{c}0.44(3) \\
* * *\end{array}$ & & $\begin{array}{c}0.36(6) \\
* * *\end{array}$ \\
\hline D1 & $\begin{array}{c}0.07(9) \\
* * *\end{array}$ & & $0.10(12)$ & & $\begin{array}{c}0.04(9) \\
* * *\end{array}$ & $* *$ & 0.09 & $*$ & $0.13(13)$ \\
\hline E1 & $0.22(10)$ & $* *$ & $0.12(9)$ & $*$ & $\begin{array}{c}0.10(7) \\
*\end{array}$ & & $\begin{array}{c}0.09(8) \\
*\end{array}$ & $* *$ & $\begin{array}{c}0.13(9) \\
* *\end{array}$ \\
\hline $\mathrm{F} 1$ & $0.27(25)$ & $* * *$ & $0.14(23)$ & & $0.10(17)$ & & $\begin{array}{c}0.09(19) \\
*\end{array}$ & & $\begin{array}{c}0.10(16) \\
*\end{array}$ \\
\hline G1 & 0.30 (19) & $* * *$ & $0.13(15)$ & & $0.15(12)$ & & 0.15 & $* * *$ & $0.10(7)$ \\
\hline B2 & $\begin{array}{c}0.16(10) \\
* *\end{array}$ & $* *$ & $0.24(13)$ & $* * *$ & $\begin{array}{c}0.67(11) \\
* *\end{array}$ & $*$ & $0.59(9)$ & $*$ & $\begin{array}{c}0.54(12) \\
* *\end{array}$ \\
\hline $\mathrm{C} 2$ & $\begin{array}{c}0.47(3) \\
* * *\end{array}$ & & $\begin{array}{c}0.37(5) \\
* * *\end{array}$ & $*$ & $\begin{array}{c}0.25(2) \\
* * *\end{array}$ & & $\begin{array}{c}1.04(2) \\
* * *\end{array}$ & & $\begin{array}{c}0.34(4) \\
* * *\end{array}$ \\
\hline D2 & $\begin{array}{c}0.07(17) \\
* * *\end{array}$ & & $0.06(23)$ & & $0.07(20)$ & & 0.11 & & $0.12(26)$ \\
\hline E2 & $0.19(10)$ & $* *$ & $0.04(5)$ & & $0.13(4)$ & & $0.09(5)$ & $* * *$ & $0.11(9)$ \\
\hline $\mathrm{F} 2$ & $\begin{array}{c}0.13(10) \\
*\end{array}$ & & $0.09(7)$ & & $\begin{array}{c}0.07(8) \\
* *\end{array}$ & & $\begin{array}{c}0.06(8) \\
* * *\end{array}$ & & $\begin{array}{c}0.10(11) \\
* * *\end{array}$ \\
\hline G2 & $0.43(9)$ & $* * *$ & $0.08(9)$ & $* * *$ & $0.05(4)$ & & $0.04(5)$ & & 0.05 (4) \\
\hline
\end{tabular}

${ }^{1}$ For example, for (A1 + A2), $150 \mathrm{~m}$ cannot be distinguished from $200 \mathrm{~m}$; at $150 \mathrm{~m}$, however, (A1 + A2) differs from B1 at $p \leq 0.05$.

marked seasonality even below the permanent thermocline (Sect. 4.1.2). Resplandy et al. (2011) in an eddy-resolving $\left(1 / 12^{\circ}\right)$ model showed the large role of vertical nutrient supply by eddies. However, as noted, for example, by Shankar et al. (2002), the regularity of the monsoons makes features like "monsoon currents", which dominated the previous views of the circulation of the upper Arabian Sea, still stand out, including their relation to the depth of the principal thermocline. For further background information, Wiggert et al. (2005) reviewed biogeochemical pelagic processes. Ramaswamy and Gaye (2006; Sta. EAST near $15^{\circ} \mathrm{N}, 65^{\circ} \mathrm{E}$ ) described ten years of biogenic vertical flux at approximately $3000 \mathrm{~m}$ depth.

The study region is largely outside the strong physical and biogeochemical activity offshore of the Arabian Peninsula and near the Murray Ridge. Similarly on its eastern side, our meridional band is largely beyond the influences of the sea level changes, currents, and Kelvin waves near the Indian Subcontinent. During the SWM period coastal upwelling reigns in the "meso-eastern-boundary-current regime" along the west coast of India, without the large eddies and offshoredrawn filaments as seen off the western side of the basin. Associated with the upwelling is the north-setting undercur- rent, which advects $\mathrm{O}_{2}$ poleward. Naqvi et al. (2006) reported low salinity and elevated $\mathrm{O}_{2}$ near the continental slope off Goa $\left(15^{\circ} \mathrm{N}\right)$ even in December in 1998 after the SWM had lasted unusually long and the surface flow was still directed toward the equator. In their eddy-resolving model, Resplandy et al. (2012) generate the undercurrent below about $150 \mathrm{~m}$ depth and stress the importance of poleward $\mathrm{O}_{2}$ advection along the continental slope.

The general distribution of salinity and $\mathrm{O}_{2}$ along $64^{\circ} \mathrm{E}$ as depicted by Olson et al. (1993: Fig. 2) for 1986 is probably valid also for $65^{\circ}$ E. Between 200 and $500 \mathrm{~m}$ depth the median temperatures at each depth horizon increase with monotonous slopes by $2-3^{\circ} \mathrm{C}$, with the medians along $67^{\circ} \mathrm{E}$ (boxes B2-G2; Supplement Table S.2) tending to be cooler by a few tenths of a degree than those along $65^{\circ} \mathrm{E}$ (boxes A1-G1). Little more will be said about temperature. Between about 7 and $10^{\circ} \mathrm{N}$, the salinity below the bottom of the pycnocline at individual stations varies little with depth to at least $800 \mathrm{~m}$ but increases northward from ca. 35.2 to 35.3-35.4. To the north of 10 or $12^{\circ} \mathrm{N}$ up to $21^{\circ} \mathrm{N}$ and between 150 and $500 \mathrm{~m}$ depth, the median salinities at each horizon increase with monotonous slopes to 35.9-36.0 (35.8 at $500 \mathrm{~m}$ near $65^{\circ}$ E; Supplement Table S.3). In the OMZ, the median 
Table 2. Median $\mathrm{NO}_{2}^{-}$concentrations $(\mu \mathrm{M})$ for all boxes near the indicated depths (number of values in parentheses; data in Table S.1.b). One-sided $p$ for $\mathrm{NO}_{2}^{-}$difference between adjoining medians in boxes $\mathrm{D}-\mathrm{G}$ : $* \leq 0.20$; $* * 0.10$; $* * * \leq 0.05$; blank, non-significant (see also footnote in Table 1).

\begin{tabular}{|c|c|c|c|c|c|c|c|c|c|}
\hline Box & $150 \mathrm{~m}$ & & $200 \mathrm{~m}$ & & $300 \mathrm{~m}$ & & $400 \mathrm{~m}$ & & $500 \mathrm{~m}$ \\
\hline $\mathrm{A} 1+\mathrm{A} 2$ & $0.01(10)$ & & $0.01(10)$ & & $0.01(7)$ & & $0.01(7)$ & & $0.01(7)$ \\
\hline B1 & 0.02 (14) & & $0.01(18)$ & & $0.00(15)$ & & $0.00(14)$ & & $0.00(14)$ \\
\hline $\mathrm{C} 1$ & $0.03(12)$ & & $0.04(18)$ & & $0.00(11)$ & & $0.00(13)$ & & $0.00(12)$ \\
\hline D1 & $\begin{array}{c}0.13(30) \\
* * *\end{array}$ & & $0.81(34)$ & $*$ & $\begin{array}{c}1.17(32) \\
* * *\end{array}$ & $* * *$ & $\begin{array}{c}0.00(29) \\
* * *\end{array}$ & $* * *$ & $\begin{array}{c}0.00(29) \\
* * *\end{array}$ \\
\hline E1 & $\begin{array}{c}0.02(15) \\
*\end{array}$ & $* * *$ & $0.40(16)$ & $* *$ & $\begin{array}{c}2.86(15) \\
* * *\end{array}$ & $* * *$ & $1.32(16)$ & $* * *$ & $\begin{array}{c}0.04(11) \\
* * *\end{array}$ \\
\hline $\mathrm{F} 1$ & $\begin{array}{c}0.04(36) \\
*\end{array}$ & $* * *$ & $0.14(45)$ & $* *$ & $\begin{array}{c}1.36(41) \\
* * *\end{array}$ & $* *$ & $\begin{array}{c}1.37(38) \\
* *\end{array}$ & $* * *$ & $0.43(37)$ \\
\hline G1 & $0.03(30)$ & $* * *$ & $0.23(34)$ & & $0.53(31)$ & & $0.75(32)$ & $* *$ & $0.54(28)$ \\
\hline B2 & $0.02(9)$ & & $0.00(9)$ & & $0.00(8)$ & & $0.00(4)$ & & $0.00(5)$ \\
\hline $\mathrm{C} 2$ & $0.00(4)$ & & $0.00(6)$ & & $0.00(5)$ & & $0.01(4)$ & & $0.00(6)$ \\
\hline D2 & $\begin{array}{c}2.00(35) \\
* * *\end{array}$ & $* * *$ & $2.83(40)$ & $* * *$ & $\begin{array}{c}1.22(38) \\
* * *\end{array}$ & $* * *$ & $\begin{array}{c}0.01(36) \\
* * *\end{array}$ & $* * *$ & $\begin{array}{c}0.00(35) \\
* * *\end{array}$ \\
\hline E2 & $0.08(16)$ & $* * *$ & $\begin{array}{c}2.53(18) \\
* *\end{array}$ & & $2.74(15)$ & $* * *$ & $\begin{array}{c}1.28(17) \\
* *\end{array}$ & $* * *$ & $\begin{array}{c}0.06(17) \\
* *\end{array}$ \\
\hline F2 & $0.07(6)$ & $* * *$ & $\begin{array}{c}1.74(9) \\
*\end{array}$ & $* * *$ & $2.82(9)$ & $* * *$ & $1.44(7)$ & $* *$ & $\begin{array}{c}0.95(5) \\
*\end{array}$ \\
\hline G2 & $0.04(12)$ & $* * *$ & $0.46(14)$ & $* * *$ & $2.67(14)$ & $* * *$ & $1.98(14)$ & $* * *$ & $1.26(13)$ \\
\hline
\end{tabular}

salinities tend to be slightly lower along $67^{\circ} \mathrm{E}$ than in the western (along $65^{\circ} \mathrm{E}$ ) boxes.

Over the range of about 7 to $10^{\circ} \mathrm{N}$, near and somewhat below $200 \mathrm{~m}, \mathrm{O}_{2}$ as measured prior to the advent of the STOX probe declines from about 2 to about $0.4 \mathrm{mLL}^{-1}(\sim 90$ to $18 \mu \mathrm{M}$; cf. Wyrtki, 1971: Tables 441 and 502; see also the numerous significant differences among median $\mathrm{O}_{2}$ values between the $\mathrm{C}$ and $\mathrm{D}$ boxes at 10 and $12^{\circ} \mathrm{N}$, respectively, in Table 1). Naqvi et al. (1993) noted that the transitional zone is observed between these two latitudes, which during 1995 was only one degree wide. The position seems to be fairly stable in time, probably owing to the distribution of wind stress and the resulting quasi-zonal circulation (Warren, 1994; but see the section for the SWM in de Sousa et al., 1996, and Supplement Sect. S.1). The very steep horizontal $\mathrm{O}_{2}$ gradients at the southern edge of the upper half of the OMZ in our meridional band, not described previously, are to be covered by Banse and Postel (2015).

\subsection{Setting of the OMZ}

\subsubsection{General hydrography}

We focus on the OMZ poleward of $12^{\circ} \mathrm{N}$. Our $150 \mathrm{~m}$, uppermost horizon is below the salinity maximum of the nonseasonal pycnocline near a $\sigma_{\mathrm{t}}$ of $24 \mathrm{~kg} \mathrm{~m}^{-3}$ and below the sharp oxycline, which is the upper border of the OMZ. The depths of these discontinuities vary seasonally (Colborn, 1975; Molinari et al., 1986), being deeper in the SWM and, in the north, also during the NEM. The climatological depths of the bottom end of the steep vertical gradients of temperature, salinity, and oxygen occur somewhat above the $200 \mathrm{~m}$ horizon (see Fig. 2 as an example). Much of the OMZ has only weak vertical gradients of $\mathrm{O}_{2}$, but zooplankton species may be layered, perhaps responding to these gradients, as found with copepods (Böttger-Schnack, 1996) and Wishner et al. (1998).

\subsubsection{Oxygen}

The intense (suboxic) OMZ extends from north of the Cboxes $\left(12^{\circ} \mathrm{N}\right)$ poleward, although in September 1994 the depths at and slightly above $200 \mathrm{~m}$ in our Box C1 were part 
of this zone (R/V T. G. Thompson cruise TN039; see also the variable latitude of the denitrification zone in Naqvi, 1991). In the $\mathrm{OMZ}$, the median visual Winkler $\mathrm{O}_{2}$ levels are often below 0.1 or even $0.05 \mathrm{mLL}^{-1}$ (Table 1). The many significant differences in the table between the 150 and $200 \mathrm{~m}$ horizons suggest restricting our treatment of the OMZ to the 200 to $500 \mathrm{~m}$ levels but adding the $150 \mathrm{~m}$ level in the D-boxes $\left(15^{\circ} \mathrm{N}\right)$. The medians for the four deeper horizons range only between 0.04 and $0.15 \mathrm{mLL}^{-1} \mathrm{O}_{2}$. Within the upper OMZ as studied here, the vertical gradients tend to be small; more often than not the differences between depth horizons are insignificant, as are the north-south differences with the exception of the G-boxes (Table 1). Regarding zonal differences, the means of the annual medians of the depths in the four western boxes are all higher than those of the eastern boxes, but the ranking of the medians in Table 1 shows significant differences only at 200 and $400 \mathrm{~m}(p=0.01$ and 0.2 , respectively).

Resplandy et al. (2012), with their eddy-resolving model, studied the factors that control the $\mathrm{O}_{2}$ balance in the OMZ. For a depth range of $250-300 \mathrm{~m}$ their computed median $\mathrm{O}_{2}$ utilization rate was $2.8 \mu \mathrm{mol} \mathrm{L}^{-1} \mathrm{a}^{-1}$ (range: 2.1-6.8 [0.06 $\left.\mathrm{mL} \mathrm{L}^{-1} \mathrm{a}^{-1}(0.05-0.15)\right] \mathrm{L}$. Resplandy, 2013, in litt., cf. their Fig. 6a CAS). They also reported for the NEM and SWM that the amplitude of seasonal $\mathrm{O}_{2}$ change from vertical eddy-driven advection was several times that from biological consumption. Similarly, McCreary et al. (2013) in a non-eddy resolving $\left(0.5^{\circ}\right)$ model determined the large role of lateral $\mathrm{O}_{2}$ advection to the central Arabian Sea. Neither paper addressed shifts on the climatological scale as we do here.

\subsubsection{Nitrite}

Within the $\mathrm{OMZ}$ and in contrast to $\mathrm{O}_{2}$, Table 2 shows many significant depth differences for $\mathrm{NO}_{2}^{-}$in spite of the great variability of concentrations. The values are large at and poleward of $15^{\circ} \mathrm{N}$ except near $150 \mathrm{~m}$ (Table 2). At $15^{\circ} \mathrm{N}$ (D-boxes), however, the high $\mathrm{NO}_{2}^{-}$values at the $150 \mathrm{~m}$ horizon indicate fairly intense denitrification in conjunction with low oxygen. In contrast, there is little denitrification at 400 and $500 \mathrm{~m}$ at $15^{\circ} \mathrm{N}$ and little in the E-boxes at $500 \mathrm{~m}$ depth, reflecting the trends to slightly higher $\mathrm{O}_{2}$ (medians, 0.10 $0.13 \mathrm{~mL} \mathrm{~L}^{-1}$ ). For the same reason, the $\mathrm{NO}_{2}^{-}$medians at 300 and $400 \mathrm{~m}$ in Box G1 decline relative to the adjoining Box $\mathrm{F} 1$. The low medians at $150 \mathrm{~m}$ in boxes $\mathrm{E} 1$ and $\mathrm{F} 2$ and at $400 \mathrm{~m}$ in the D-boxes, though, hide the fact that several to many high values were present along with zero concentrations (see Supplement Table S.1.b). The map of high and low values of $\mathrm{NO}_{2}^{-}$at the $250 \mathrm{~m}$ horizon in Bobko and Rodionova (2006) from the central and northern Arabian Sea illustrates the role of downwelling from eddies to appreciable depths (cf. Artamonov, 2006).

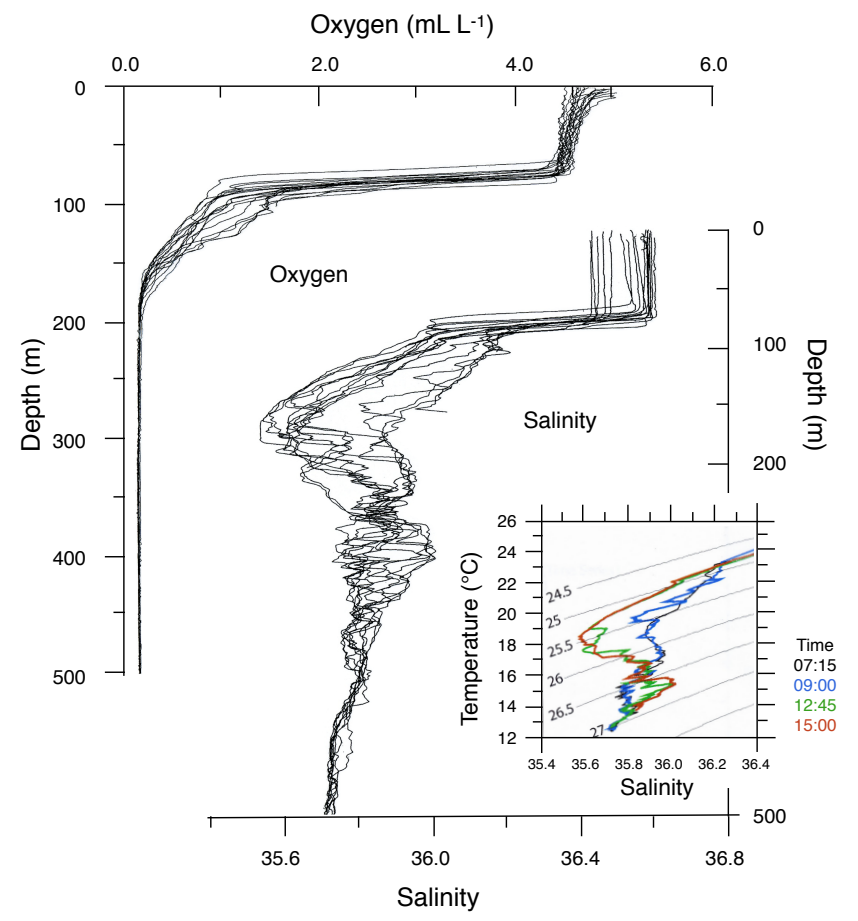

Fig. 2. Sta. 4010 of R/V Sagar Sampada near $19^{\circ} \mathrm{N}, 67^{\circ} \mathrm{E}$ (circle in Fig. 1) in January 1998. (a) Salinity and (b) $\mathrm{O}_{2}$ records from the CTD casts taken over $25 \mathrm{~h}$, most of them hourly until 16:45 LT. The ship drifted by about $41 \mathrm{~km}$ between the first and last casts; (c) $T-S$ diagram for four of the casts during the first $8 \mathrm{~h}$ (drift, about $13 \mathrm{~km}$ ).

\subsubsection{Day-to-day and weekly variability}

Using four examples, the section demonstrates that a number of relatively small water masses with apparently different biochemical history are frequently present and often on the same density surfaces. The highly dynamic nature of the hydrography creates temporal as well as spatial variability even in the central Arabian Sea at the same stations with repeated casts and is especially noticeable on week-long drift stations. For the area treated herein, previous papers emphasized temperature (isopleths), twice for four days in Box E2 (Ramesh Babu et al., 1981), as well as one and two weeks of mean isopleths of four stations centered in Box C1, both to $200 \mathrm{~m}$ (Rao, 1987), or temperature and salinity for 13 days (Prasanna Kumar et al., 2001; Naqvi et al., 2002).

In Table 3 the first two examples present among-days variability for temperature, salinity, $\mathrm{O}_{2}$, and $\mathrm{NO}_{2}^{-}$on stations near Box D1 and in Box E1, each maintained within 1-2 km. The standard deviations (SD) for $\mathrm{O}_{2}$ are absolutely small, but may be as high as the low means. On both stations the variability of $\mathrm{NO}_{2}^{-}$at $200-400 \mathrm{~m}$ is very large (the variance being larger than the mean), in part because of zero values but in part so even among the high concentrations, as will also be apparent in later sections. Measurements with fewer repeats on seven other locations in our data sets, including 
Table 3. Mean values with SD on drift stations (number of samples in parentheses).

\begin{tabular}{|c|c|c|c|c|c|}
\hline & $150 \mathrm{~m}$ & $200 \mathrm{~m}$ & $300 \mathrm{~m}$ & $400 \mathrm{~m}$ & $500 \mathrm{~m}$ \\
\hline \multicolumn{6}{|c|}{ SK 99:17, 19-21 February 1995, west of $\mathrm{D} 1 *\left(\mathrm{O}_{2}\right.$ automated end point $)$} \\
\hline$T\left({ }^{\circ} \mathrm{C}\right)$ & $18.95 \pm 0.50(7)$ & $16.63 \pm 0.27(7)$ & $13.96 \pm 0.09(8)$ & $12.86 \pm 0.07(6)$ & $12.18 \pm 0.09(5)$ \\
\hline$S$ & $35.69 \pm 0.04(7)$ & $35.73 \pm 0.01(7)$ & $35.64 \pm 0.01(8)$ & $35.61 \pm 0.01(6)$ & $35.60 \pm 0.01(5)$ \\
\hline $\mathrm{O}_{2}\left(\mathrm{~mL} \mathrm{~L}^{-1}\right)$ & $0.30 \pm 0.065$ & $0.05 \pm 0.03$ & $0.05 \pm 0.03(6)$ & $0.08 \pm 0.08$ & $0.09 \pm 0.09(7)$ \\
\hline $\mathrm{NO}_{2}^{-}(\mu \mathrm{M})$ & $0.06 \pm 0.11(7)$ & $0.90 \pm 0.85(6)$ & $2.36 \pm 0.47(7)$ & $0.05 \pm 0.08(5)$ & $0(5)$ \\
\hline \multicolumn{6}{|c|}{ ME 32/3:243-252, 10-18 May 1995, E1** ( $\mathrm{O}_{2}$ automated end point); $T$ and $S$ include sta. 240 of 9 May } \\
\hline$T\left({ }^{\circ} \mathrm{C}\right)$ & $20.94 \pm 0.45(9)$ & $17.54 \pm 0.13$ & $15.10 \pm 0.27$ & $13.57 \pm 0.10$ & $11.49 \pm 0.10(11)$ \\
\hline$S$ & $35.94 \pm 0.13(9)$ & $35.62 \pm 0.02(11)$ & $35.82 \pm 0.06(12)$ & $35.76 \pm 0.02(11)$ & $35.57 \pm 0.01$ \\
\hline $\mathrm{O}_{2}\left(\mathrm{~mL} \mathrm{~L}^{-1}\right)$ & $0.31 \pm 0.31$ & $0.08 \pm 0.015$ & $0.09 \pm 0.02(5)$ & $0.08 \pm 0.02(7)$ & - \\
\hline $\mathrm{NO}_{2}^{-}(\mu \mathrm{M})$ & $0.04 \pm 0.02(13)$ & $3.54 \pm 0.77(10)$ & $2.86 \pm 0.82(4)$ & $2.36 \pm 0.58(7)$ & - \\
\hline \multicolumn{6}{|c|}{ SK 121:8, 10-22 February 1997, western edge of G1*** ( $\mathrm{O}_{2}$ visual end point) } \\
\hline$T\left({ }^{\circ} \mathrm{C}\right)$ & $20.23 \pm 0.57(24)$ & $18.08 \pm 0.25$ & $15.78 \pm 0.38$ & $14.05 \pm 0.26(23)$ & $13.06 \pm 0.19(23)$ \\
\hline$S$ & $35.99 \pm 0.06(22)$ & $35.89 \pm 0.06(18$ & $36.03 \pm 0.07(23)$ & $35.85 \pm 0.05(23)$ & $35.77 \pm 0.03(23)$ \\
\hline $\mathrm{O}_{2}\left(\mathrm{~mL} \mathrm{~L}^{-1}\right)$ & $0.25 \pm 0.20(27)$ & $0.04 \pm 0.04$ & $0.06 \pm 0.04(26)$ & $0.05 \pm 0.04$ & $0.06 \pm 0.07(27)$ \\
\hline $\mathrm{NO}_{2}^{-}(\mu \mathrm{M})$ & $0.03 \pm 0.06(27)$ & $0.57 \pm 0.79(24)$ & $0.38 \pm 0.86(27)$ & $0.85 \pm 0.99(27)$ & $0.34 \pm 0.60(27)$ \\
\hline
\end{tabular}

U.S. JGOFS cruises, other than the following ones show similar variability. The third set of data in Table 3 come from a drift station near $21^{\circ} \mathrm{N}$, where temporal and spatial variability change cannot be separated, but the spatial range of almost half a degree is relevant to comparisons of stations on sections with one-degree spacing (see also Supplement Fig. S.3.1).

The fourth example (Fig. 2) illustrates within-station and within-day variability of hydrography south of Box D2 by 16 casts during a $28 \mathrm{~h}$ drift of about $41 \mathrm{~km}$ extent where spatial and temporal inhomogeneity came into play. The $T-S$ diagram for the first $8 \mathrm{~h}$ (Fig. 2c) shows massive replacement of water between about 100 and $300 \mathrm{~m}$, below the principal pycnocline.

Last, an inkling of large-scale distributions is provided by the $\mathrm{NO}_{2}^{-}$at $250 \mathrm{~m}$ depth on a one-half to two-thirds degree grid during the spring intermonsoon of 1990 , coupled with the associated $\mathrm{O}_{2}$ at the horizon and vertical sections indicating deep-reaching eddies in Bobko and Rodionova (2006: Figs. 5.6 and 5.11B).

The geographical heterogeneity is also to be expected in regional surveys or in interannual studies at fixed locations. Therefore, data from a few stations must not be overinterpreted.

\subsubsection{Oxygen and nitrite co-occur temporally}

The observations about hydrographic variability support our assumption set forth toward the end of Sect. 1 that $\mathrm{O}_{2}$ and $\mathrm{NO}_{2}^{-}$may co-exist temporally in the OMZ. Of course, they exclude each other spatially below the $\mathrm{O}_{2}$ threshold for the onset of denitrification of $<0.002 \mathrm{mLL}^{-1}(<0.09 \mu \mathrm{M})$. As stated, $21 \%$ of 707 samples contained $\leq 0.02 \mu \mathrm{M} \mathrm{NO}_{2}^{-}$; the majority showed zero or $0.01 \mu \mathrm{M} \mathrm{NO}_{2}^{-}$; the averages include $\mathrm{NO}_{2}^{-}$data not accompanied by $\mathrm{O}_{2}$ (Supplement Table S.1.b). In view of the aforementioned salinity spikes reflecting stratification (also Fig. 2), we visualize the dimensions of such patches horizontally to be much larger than vertically. On the average the patches must last many months, if not a year, such that planktonic animals (e.g., copepods) live and persist in an otherwise nearly anoxic milieu of a few tens of nanomoles of $\mathrm{O}_{2}$ (see also the large "patches" found in 1960 as free of $\mathrm{NO}_{2}^{-}$at the end of Sect. 3.2.4).

\subsubsection{Animal life}

This section and Supplement Sect. S.4 show that even the upper OMZ of the Arabian Sea with the $\mathrm{NO}_{2}^{-}$maximum is biologically not functionally anoxic, in contrast to the suggestion by Thamdrup et al. (2012) for much of the upper OMZ in the eastern South Pacific. Metazoan zooplankton, which by its nature requires dissolved $\mathrm{O}_{2}$, is found year round. As mentioned above, $\mathrm{NO}_{2}^{-} \leq 0.02 \mu \mathrm{M}$ (i.e., zero within the precision of the analysis) was measured in one-fifth of our samples from the 200 to $400 \mathrm{~m}$ horizons of the upper OMZ with its SNM. Thus enough $\mathrm{O}_{2}$ is present in such samples to prevent denitrification and is sufficient to maintain a reduced number of animal species and specimens.

Supplement Sect. S.4 reviews results of zooplankton collections for the plankton minimum in the upper OMZ of the 
Arabian Sea. Only nighttime data are considered, which exclude the diel migrators among plankton and nekton entering the top of the OMZ during daytime but which during the night in the mixed layer pay off the $\mathrm{O}_{2}$ debt incurred at depth. The lowest specimen numbers of a few species of copepods were $10-20 \mathrm{~m}^{-3}$ (Böttger-Schnack, 1996) and several tens per $1000 \mathrm{~m}^{3}$ of individual species of calanoid copepods (Wishner et al., 1998). Wet weights seem to range from 1 to $5 \mathrm{mg} \mathrm{m}^{-3}$. The first author remarked on the large fraction of copepod carcasses and exoskeletons. Ignatyev (2006) reported that on the average one-fifth to two-fifths of wet weight caught by mid-water trawls of $0.5 \mathrm{~mm}$ mesh size consisted of unidentifiable remainders of gelatinous animals. These were in addition to the one-third of wet weight of coelenterates in anticyclonic eddies and three-fifths of tunicates alone in cyclonic eddies.

Below the minimum in slightly better oxygenated water, copepod numbers tended to increase tenfold, as did the biomass, before declining toward depth at $>1 \mathrm{~km}$. Species occurrence in the secondary biomass maximum was layered, presumably in response to $\mathrm{O}_{2}$ (Wishner et al., 1998).

The animal distribution in the upper OMZ of the Arabian Sea is not unique. Similar features, including the minima of biomass and number of species, are found in the OMZ of the Costa Rica Dome of the eastern tropical Pacific, including the secondary maximum of biomass and species occurrence in the lower part of the OMZ (Saltzman and Wishner, 1997). In the same region, Vinogradov et al. (1991), using plankton hauls and visual observations from a submersible, confirmed the similarity of vertical patterns between the Arabian Sea and the Costa Rica Dome but added the large contribution of biomass by gelatinous animals, which are a part of the OMZ fauna. Jelly-like animals accounted for $92 \%$ of wet mass and $16 \%$ of carbon to the meso- and macroplankton in the upper $500 \mathrm{~m}$, omitting very large $(>15 \mathrm{~cm})$ but rare medusae and ctenophores (see also Hamner et al., 1975, and Supplement Sect. S.4).

\subsubsection{Nitrate deficit}

The maximum of the $\mathrm{NO}_{3}^{-}$deficit resulting from denitrification is also observed in the core of the OMZ, although tending to be a few tens of meters deeper than the $\mathrm{NO}_{2}^{-}$ maximum (Morrison et al., 1999: Fig. 8); the deficit was calculated by the NO approach, which below about $250 \mathrm{~m}$ depth might yield slight overestimates (Naqvi and Sen Gupta, 1985: Fig. 2). Other authors are Mantoura et al. (1993) and Chang et al. (2012). The maximal values in a season or a cruise range between about 2 and $15 \mu \mathrm{M}$. As illustrated by Morrison et al. (1999) for 1995, the deficit declines toward depth and vanishes by $600-900 \mathrm{~m}$, while $\mathrm{NO}_{2}^{-}$is not observed below $350 \mathrm{~m}$ depth (below $600 \mathrm{~m}$ at one of their four stations). However, note that the presence of an $\mathrm{NO}_{3}^{-}$deficit does not reflect ongoing anoxia. Rather, the deficit regularly observed in the OMZ well below the deficit maximum, not accompanied by $\mathrm{NO}_{2}^{-}$, is apt to be due to mixing downward from the depth of maximum. In the northeastern Arabian Sea, Naqvi et al. (1990) observed lower $\mathrm{NO}_{3}^{-}$deficits during the SWM period of 1987 than during the NEM period of 1988 (2-3 $\mu \mathrm{M}$ versus $8-9 \mu \mathrm{M}$, respectively).

\section{Seasonal and decadal variability in the $\mathrm{OMZ}$}

Besides a $T-S$ diagram of seasonal medians for the boxes (Fig. 3), the principal method of study is linear regression of the variable of interest on year (decimal fractions according to the month of observation). Decadal changes of temperature are not considered because linear regressions of sampling depth on year unexpectedly showed positive or negative trends. We neglect this source of possible bias for salinity, oxygen, and nitrite because of the much smaller vertical gradients at the horizons of concern.

\subsection{Temperature and salinity}

\subsubsection{Temperature}

By the climatology of temperature of the upper $500 \mathrm{~m}$, the $20^{\circ} \mathrm{C}$ isotherm in the middle of the thermocline in our region moves seasonally by about $50 \mathrm{~m}$ (Molinari et al., 1986). Ramesh and Krishnan (2005) studied the seasonal downward flux of heat to $\geq 200 \mathrm{~m}$ as zonal averages between 50 and $70^{\circ} \mathrm{E}$, for $0-20^{\circ} \mathrm{N}$. Presumably, $\mathrm{O}_{2}$ is also transported (cf. Sect. 1). They calculated that downwelling from convergence and horizontal advection, and the deepening and cooling of the upper layer coupled with strong vertical diffusivity from wind-caused turbulence, warmed the thermocline near 150,200 , and $250 \mathrm{~m}$ depths south of $12-13^{\circ} \mathrm{N}$ by about 1.2 , 0.9 , and $0.4^{\circ} \mathrm{C}$, respectively. Their Figs. 6,8 , and 9 also illustrate that the OMZ area of our study is largely outside the centers of the greatest hydrographic and associated changes in the western and southern Arabian Sea. Finally, the 2-year time series by an Argo float, launched at $12^{\circ} \mathrm{N}, 65^{\circ} \mathrm{E}$ and slowly drifting toward the southeast (Prakash et al., 2012), illustrates an apparently seasonal vertical shift of the top of the oxycline, the extremes ranging between $35-40$ and $130 \mathrm{~m}$ depth (during the early NEM and the SI, respectively).

\subsubsection{Temperature-salinity relations}

Our $T-S$ diagram (Fig. 3; cf. Fig. 1) is based on medians of discrete data and presents the climatology for the OMZ in our meridional swath. Obvious are the strikingly differing patterns at the 150 and $200 \mathrm{~m}$ horizons down to the isopycnals $\left(\sigma_{\mathrm{t}}\right)$ of $26.3-26.4 \mathrm{~kg} \mathrm{~m}^{-3}$ versus those at the 300 to $500 \mathrm{~m}$ levels. The former are dominated by seasonal, seemingly diapycnal warming to $>200 \mathrm{~m}$ depth (but $<300 \mathrm{~m}$ ) in boxes $\mathrm{B}-\mathrm{G}$, extending well below the permanent pycnocline. In contrast, the three lower horizons exhibit clear isopycnal, seasonally periodic change at and poleward of the D-boxes 


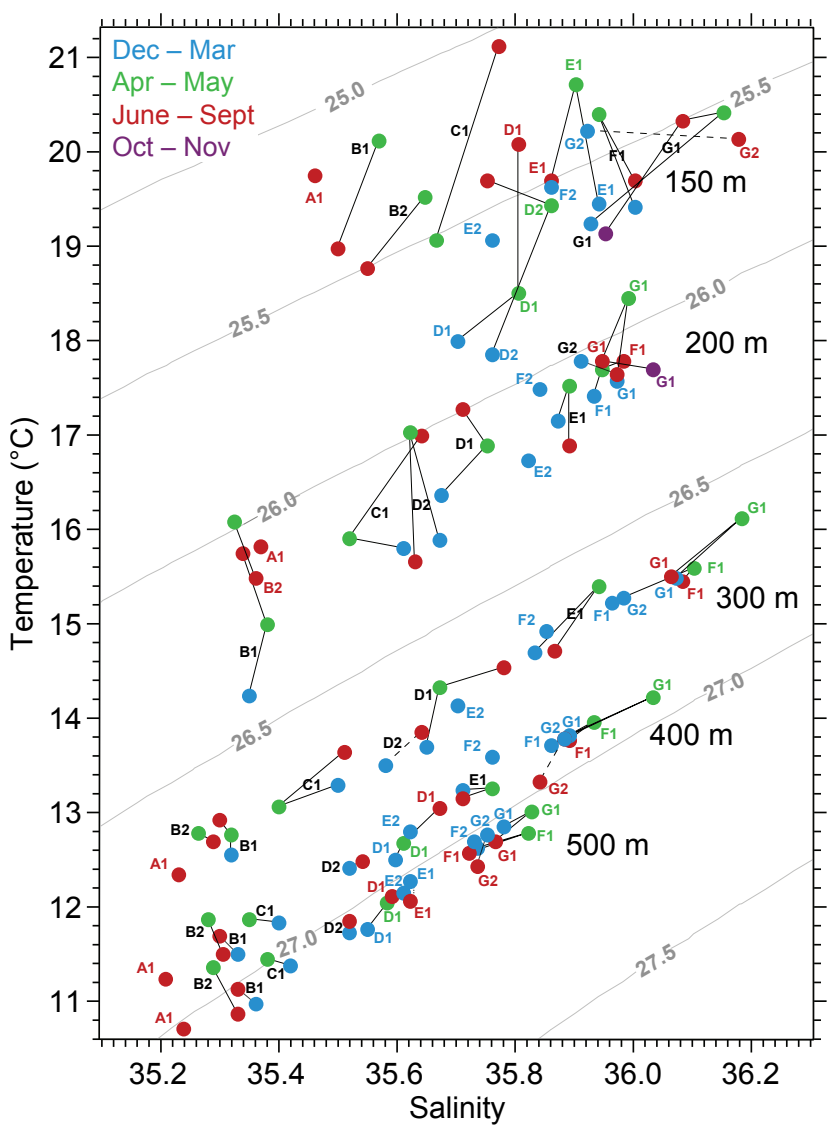

Fig. 3. $T-S$ diagram for medians with $\geq 4$ pairs per season of temperature and salinity in the boxes of our database (Table S.1.b). The seasons are defined as northeast monsoon: December-March (blue, NEM); spring intermonsoon: April-May (green, SI); southwest monsoon: June-September (red, SWM); and fall intermonsoon: October-November (purple, FI). Colored and black indices for single seasons and entire boxes, respectively. Adjoining seasons of each box connected by full lines, otherwise by broken lines. The slanted background lines are isopycnals $\left(\sigma_{\mathrm{t}}, \mathrm{kg} \mathrm{m}^{-3}\right)$.

(i.e., in the $\mathrm{OMZ})$. Box $\mathrm{C} 1\left(12^{\circ} \mathrm{N}\right)$ at least at the $300 \mathrm{~m}$ horizon seems to follow this "deep" pattern. In the B-boxes $\left(10^{\circ} \mathrm{N}\right)$ the seemingly diapycnal warming is observed even at $500 \mathrm{~m}$, where the median temperatures ranges seasonally by $0.4-0.5^{\circ} \mathrm{C}$; the maximal and minimal values differ significantly in Box B2.

As expected from the climatology of Ramesh and Krishnan (2005: Fig. 4) for 150 and $200 \mathrm{~m}$, the lowest median temperatures at these horizons tend to occur during the NEM, while the highest medians are found during the SI or SWM at $150 \mathrm{~m}$ up to $20^{\circ} \mathrm{N}$ (Boxes F1, F2) and at $200 \mathrm{~m}$ to $18^{\circ} \mathrm{N}$ (Box E1; at $200 \mathrm{~m}$ also in $\mathrm{G} 1,21^{\circ} \mathrm{N}$, but not at $150 \mathrm{~m}$ ). At the $300 \mathrm{~m}$ horizon in Box $\mathrm{C} 1$ and the D-boxes the weak temperature rise of the SWM is accompanied by a marked increase of salinity. Regrettably, no or insufficient ( $<4$ pairs) observations are available in all these boxes for the FI season for seeing whether the medians return to the vicinity of the
NEM (winter) values, as they do (or tend to do) in Box G1 at all depths.

According to the eddy-resolving model of Resplandy et al. (2011), the diapycnal heat transport demonstrated in Fig. 3 between 12 and $21^{\circ} \mathrm{N}$ is principally due to vertical advection and mixing by eddies but less so to horizontal advection. The apparently efficient mechanism(s) transmitting heat and, presumably, $\mathrm{O}_{2}$ to the 150 and $200 \mathrm{~m}$ horizons in the climatology during the SI is not obvious when the seasonal heating forms a thermocline in the upper $50 \mathrm{~m}$ or so.

At the 300 to $500 \mathrm{~m}$ horizons, temperature and salinity increase and decrease in a periodic, isopycnal manner (Fig. 3). Both properties tend to be highest during the SI and SWM periods, as is the case for temperature also at the upper horizons. Note the somewhat elevated salinities at $300 \mathrm{~m}$, relative to the two deeper horizons at a density close to that of the Persian Gulf intrusion from Box $\mathrm{C} 1\left(12^{\circ} \mathrm{N}\right)$ poleward. At depth, most temperature differences between the warmest and coolest seasons in the E- to G-boxes are significant, in part highly so ( $p=0.01$ to 0.05 ). The increases suggest horizontal advection, with more northerly water tending to be present during the SI period. The salinity increases tend to be more pronounced in the western boxes.

For boxes D1, D2, and G1, zonal seasonal data means and medians of temperature and salinity were also drawn from the averages in the World Ocean Data Base 2001 (Levitus et al., 2002; http://iridl.ldeo.columbia.edu/SOURCES/.NOAA/ .NODC/WOA01/). They indicate mild east-west gradients, with both variables tending to increase toward the west, which for temperature is in contrast to Fig. 3. The temperature maxima occur during the SI or SWM seasons. Further, in Box D2 between 250 and $500 \mathrm{~m}$ the FI period exhibits large salinity increases $(0.05-0.1)$ accompanied by slight declines of temperature. Similar temperature decreases are observed in Box D1. In view of the critique by Bianchi et al. (2012) regarding artifacts arising from averaging and interpolating of $\mathrm{O}_{2}$ data as used in the World Ocean Data Base, which in part applies to other variables, we lean toward giving more credence to our own medians, which are simply based on discrete samples.

Disregarding the small differences between our and Levitus' data, the principal conclusion from Fig. 3 for the OMZ (Boxes D-G) is the evidence of significant seasonal, periodic advection along isopycnals at $300-500 \mathrm{~m}$ depth, most marked during the SI and/or the SWM periods. Because temperature and salinity together increase at that time, the transport direction must be from the northern to the southern quadrants.

\subsubsection{Decadal change of salinity}

The general distribution of salinity was described earlier. For the climatological change, Supplement Table S.4 provides the regression slopes for salinity on year for all boxes and depth ranges for 3-4 decades, while Table S.5 presents 
seasonal regression on year for the OMZ when $\geq 15$ contiguous years were available. For boxes A-C $\left(8-12^{\circ} \mathrm{N}\right)$ all slopes except two in Supplement Table S.4 are positive, and the majority significantly so $(p \leq 0.2)$; over a period of 40 years the median salinity increase estimated from the slopes was 0.11. In contrast, in the OMZ in and poleward of the D-boxes $\left(15^{\circ} \mathrm{N}\right)$ negative values also occurred, especially at $15^{\circ} \mathrm{N}$; here the median salinity decrease from the regression slopes over 40 years was 0.06 . The observations support our earlier conclusion that there is little if any continuity of the OMZ with the region adjoining to the south. At $20-21^{\circ} \mathrm{N}$ salinity tended to increase. In boxes F2, G1, and G2 at 200-500 m, the median increase from the slopes was $0.0034 \mathrm{a}^{-1}(n=5)$, which corresponds to 0.13 over four decades.

\subsection{Oxygen}

\subsubsection{Seasonal variability of $\mathrm{O}_{2}$ concentrations}

Previous studies suggested either slightly better aeration during the SWM than in the NEM seasons in the upper few hundred meters of the OMZ (Naqvi, 1987; Naqvi et al., 1990; de Sousa et al., 1996) or did not find seasonal changes of $\mathrm{O}_{2}$ (Morrison et al., 1999). Except for Naqvi (1987), the cited papers were based on only two cruises or (Morrison et al., 1999) several cruises during one year. They could not distinguish between seasonal and interannual changes of $\mathrm{O}_{2}$. In contrast, with often four decades of observations for many boxes in our longitudinal band in hand, which include the above cited measurements by Naqvi and de Sousa, we treat climatology. In view of the strong advective processes (cf. Fig. 3) and the significant seasonal $\mathrm{O}_{2}$ differences (Fig. 4), the apparently fairly steady secular maintenance of the annual balance between relatively rapid utilization and advection at the low prevailing $\mathrm{O}_{2}$ concentrations is truly remarkable.

The $150 \mathrm{~m}$ horizon is given short shrift because of the substantial interaction with surface waters (Fig. 3). A methodological problem in interpreting our $\mathrm{O}_{2}$ and $\mathrm{NO}_{2}^{-}$data, besides the accuracy of the $\mathrm{O}_{2}$ analyses, is the possible compounding of seasonal with decadal changes, which we disregarded for temperature and salinity. So, for comparisons among seasons we juxtapose similar years and focus on the NEM and SI versus the SWM seasons (December-May and June-September, respectively) in boxes D2 and F1 of the core of the OMZ. These boxes each offer a pair of regressions for the 200-500 $\mathrm{m}$ horizons for similar years in both seasons (Fig. 4, open symbols; Table 4). All of the comparisons of medians in Table 4 are significant, at least at $p=0.2$.

Table 5 contains the statistics for all seasonal data with $\geq 5$ points (note some differences for periods between Fig. 4 and Table 5). As will be discussed in full in the next subsection, all slopes are negative (i.e., oxygen was decreasing with year) and significantly so (at $p \leq 0.2$ ) in 7 out of 10 regression equations in Table 5 for Box D2.
The principal and surprising result about seasonality in the upper OMZ is that at all depths, the NEM and SI periods exhibit the higher $\mathrm{O}_{2}$ values and only in one is the SWM value the higher one of the pair. We are struck by the relative regularity of our data, although they are strongly biased upward as judged by the STOX observations. The similarity of the patterns (Fig. 4), especially the near-constant median $\mathrm{O}_{2}$ concentrations (cf. Table 1) in spite of the great differences of processes acting at the $200 \mathrm{~m}$ (diapycnal) and the 300 to $500 \mathrm{~m}$ levels (isopycnal; see Fig. 3), is truly noteworthy.

Regarding the causes of the seasonality, the high primary production of the SWM and the presumably enhanced vertical flux of particulate matter (see the sediment trap data at greater depths than our treatment near $15^{\circ} \mathrm{N}$ in Ramaswamy and Gaye, 2006) could be expected to lead to higher $\mathrm{O}_{2}$ consumption and lower $\mathrm{O}_{2}$ concentrations. Obviously, however, consumption cannot cause the seasonal increase of $\mathrm{O}_{2}$ during the NEM and SI periods, so the seasonal climatological progression of $\mathrm{O}_{2}$ concentrations must principally be governed by advection. As noted in Sect. 4.1.2, at the 300 to $500 \mathrm{~m}$ levels the $T-S$ diagram (Fig. 3) indicates isopycnal advection, most conspicuously during the FI period, with the transport direction during that time apparently from north to south in view of the increase of salinity to the north. While there is a tendency to a mild increase of $\mathrm{O}_{2}$ in the far north (G-boxes, Table 1), the meridional gradients of the overall medians are smaller than would be expected from the seasonal ratios in Tables 4 and 5, so that $\mathrm{O}_{2}$ must also be supplied zonally.

According to the model for the CAS domain of the central Arabian Sea by Resplandy et al. $(2011,2012)$, the vertical advection is most intensive in the upper OMZ (200$400 \mathrm{~m}$ ), where the model similar to those in our observations yields increases of the $\mathrm{O}_{2}$ values in the FI and NEM seasons and decreases in the late SI and SWM due to upward Ekman pumping. Further, Resplandy et al. (2012) stated for the NEM and SWM periods that the temporal $\mathrm{O}_{2}$ change from vertical eddy-driven processes was 3-5 times that from biological consumption. The authors, however, estimated an annual amplitude of $6 \mu \mathrm{M}$ of seasonal change in the upper OMZ to be "of the order of $5 \%$ " of the annual mean $\mathrm{O}_{2}$ concentrations of $40 \mu \mathrm{M}$. The range in the core and the lower OMZ was $1-3 \mu \mathrm{M}$ of the concentrations of $20-40 \mu \mathrm{M}$ (Resplandy et al., 2012: p. 5105). In contrast, we find median and mean differences of 0.08 and $0.10 \mathrm{~mL} \mathrm{~L}^{-1}$, respectively $(\sim 4.0 \mu \mathrm{M}$; range, $\left.0.03-0.20 \mathrm{~mL} \mathrm{~L}^{-1}\right)$, of the 14 pairs " $>$ SWM" in Table 4 . They amount to 76 and $91 \%$, respectively, of the 0.105 and $0.11 \mathrm{mLL}^{-1}(\sim 4.5 \mu \mathrm{M})$ as median and mean, respectively, of the 13 median $\mathrm{O}_{2}$ concentrations for these boxes and depths (Table 1). The seasonality is strong. Using a different model McCreary et al. (2013) likewise recognized the poleward horizontal advection and the role of the vertical advection of $\mathrm{O}_{2}$.

Finally, even when neglecting our newly evaluated historical data it is no longer advisable to base $\mathrm{O}_{2}$ budgets for the 

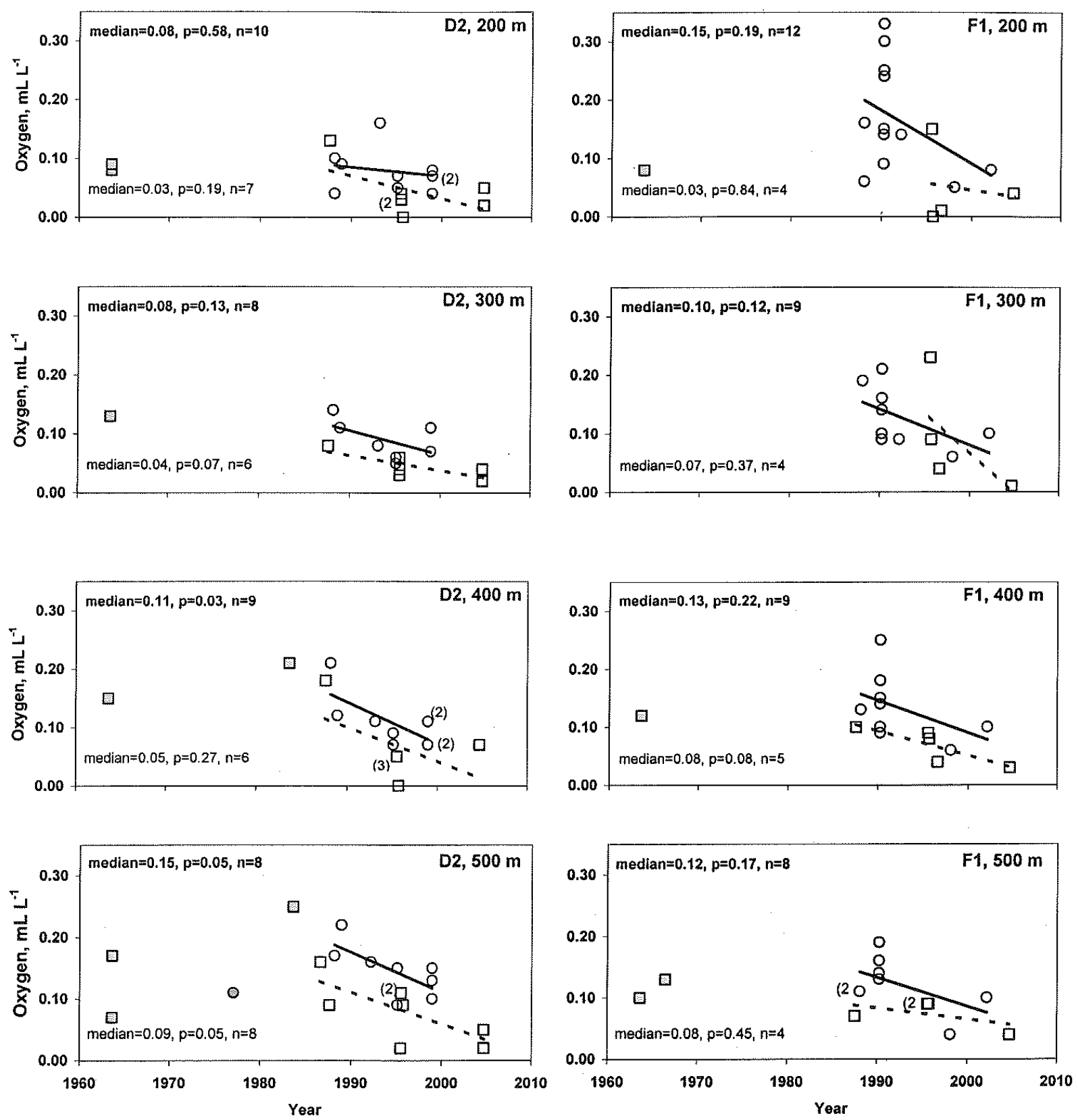

Fig. 4. Examples of regressions of oxygen observations on year for similar years with data for the NEM (circles, bold line, and text in upper part of panels) and SWM (squares, dashed line, and text in lower part of panels) for Boxes D2 and F1, chosen because two seasons were available for all depths, with medians, $p$ for slopes, and number of values $(n)$. Shaded symbols not included in regressions.

central Arabian Sea on data from a single or even several cruises executed during only one season.

\subsubsection{Four-decadal changes of $\mathrm{O}_{2}$ in the upper $\mathrm{OMZ}$}

Neglecting the $150 \mathrm{~m}$ horizon in Table 5 , the slopes of the 29 seasonal regressions - half being significant - are overwhelmingly negative, except in the northernmost boxes F2, G1, and G2. Thus, $\mathrm{O}_{2}$ decreased. Three slopes at depth in F2 $\left(20^{\circ} \mathrm{N}\right)$ are positive with very high significance, which proves that the decrease in the bulk of our meridional swath is real rather than an artifact from an accuracy of the Winkler analyses increasing with time.

Supplement Table S.6 shows the computed annual slopes for $\mathrm{O}_{2}$ concentrations on year for all boxes and depth ranges with $\geq 5$ values each for 3 to 4 decades. Two remarkable results are (1) the signs of the slopes for most depths in the southern boxes $\left(\mathrm{A}-\mathrm{C}, 8-12^{\circ} \mathrm{N}\right)$ are positive, indicating an increasing trend in dissolved $\mathrm{O}_{2}$ within the 
Table 4. Significant seasonal differences in median $\mathrm{O}_{2}$ concentrations $\left(\mathrm{mLL}^{-1}\right)$ in the $\mathrm{OMZ}$ for boxes and depths with $\geq 2$ values during similar periods. One-sided $p: *, \leq 0.20 ; * *, \leq 0.10 ; * * *, \leq 0.05$. See Fig. 3 for names of seasons and months.

\begin{tabular}{|c|c|c|c|c|c|}
\hline Box & $\begin{array}{l}\text { Depth } \\
\text { (m) }\end{array}$ & Year & Season & $p$ & $n^{\dagger}$ \\
\hline \multirow[t]{3}{*}{ D1 } & 200 & 1963-1996 & $\mathrm{SWM}>\mathrm{SI}$ & $0.20 *$ & $(0.12 / 0.00 ; 8 / 3)$ \\
\hline & 400 & 1994-1996 & $\mathrm{SI}>\mathrm{SWM}$ & $0.10 * *$ & $(0.20 / 0.09 ; 2 / 3)$ \\
\hline & 500 & 1994-1996 & $\mathrm{SI}>\mathrm{SWM}$ & $0.10 * *$ & $(0.24 / 0.13 ; 2 / 3)$ \\
\hline \multirow[t]{4}{*}{$\mathrm{F} 1$} & 400 & 1987-2004 & $\mathrm{NEM}>\mathrm{SWM}$ & $0.01 * * *$ & $(0.13 / 0.08 ; 9 / 5)$ \\
\hline & 500 & 1987-2004 & $\mathrm{NEM}>\mathrm{SWM}$ & $0.01 * * *$ & $(0.12 / 0.08 ; 8 / 4)$ \\
\hline & 200 & 1990-1996 & $\mathrm{SI}>\mathrm{SWM}$ & $0.10 * *$ & $(0.20 / 0.01 ; 4 / 3)$ \\
\hline & 300 & 1990-1996 & $\mathrm{SI}>\mathrm{SWM}$ & $0.20 *$ & $(0.17 / 0.09 ; 3 / 3)$ \\
\hline \multirow[t]{6}{*}{ G1 } & 300 & 1988-1994 & $\mathrm{NEM}>\mathrm{SI}$ & $0.10 * *$ & $(0.19 / 0.15 ; 4 / 4)$ \\
\hline & 400 & $1987-1997$ & $\mathrm{NEM}>\mathrm{SWM}$ & $0.20 *$ & $(0.15 / 0.04 ; 4 / 2)$ \\
\hline & 200 & 1988-1990 & $\mathrm{SI}>\mathrm{NEM}$ & $0.05 * * *$ & $(0.29 / 0.13 ; 3 / 3)$ \\
\hline & 400 & 1988-1990 & $\mathrm{SI}>\mathrm{NEM}$ & $0.10 * *$ & $(0.21 / 0.16 ; 2 / 3)$ \\
\hline & 200 & 1987-1996 & $\mathrm{SI}>\mathrm{SWM}$ & $0.05 * * *$ & $(0.27 / 0.07 ; 3 / 3)$ \\
\hline & 400 & 1987-1996 & $\mathrm{SI}>\mathrm{SWM}$ & $0.05 * * * \dagger \dagger$ & $(0.21 / 0.04 ; 2 / 2)$ \\
\hline \multirow[t]{5}{*}{ D2 } & 200 & 1987-1998 & $\mathrm{NEM}>\mathrm{SWM}$ & $0.05^{* * *}$ & $(0.08 / 0.03 ; 10 / 5)$ \\
\hline & 300 & 1987-1998 & $\mathrm{NEM}>\mathrm{SWM}$ & $0.10 * *$ & $(0.08 / 0.05 ; 8 / 4)$ \\
\hline & 400 & 1983-1998 & $\mathrm{NEM}>\mathrm{SWM}$ & $0.10 * *$ & $(0.11 / 0.05 ; 9 / 6)$ \\
\hline & 400 & 1980-1996 & $\mathrm{FI}>\mathrm{SWM}$ & $0.10 * *$ & $(0.20 / 0.05 ; 4 / 6)$ \\
\hline & 500 & 1980-1996 & $\mathrm{FI}>\mathrm{SWM}$ & $0.05^{* * *}$ & $(0.19 / 0.11 ; 3 / 7)$ \\
\hline
\end{tabular}

depth range examined $(200-500 \mathrm{~m})$. The median slope is $0.0024 \mathrm{~mL} \mathrm{~L}^{-1} \mathrm{a}^{-1}\left(n=12 ; 0.013 \mathrm{~mL} \mathrm{~L}^{-1} \mathrm{a}^{-1}\right.$ for the two significant slopes; $(\sim 0.1$ and $0.6 \mu \mathrm{M}))$. (2) Within the OMZ, in contrast, $\mathrm{O}_{2}$ concentrations appear to have been decreasing, almost without exception, over four decades until the mentioned boxes $\mathrm{F} 2, \mathrm{G} 1$, and $\mathrm{G} 2\left(20-21^{\circ} \mathrm{N}\right)$ are reached. In boxes D1-F1 (the central OMZ after excluding the $150 \mathrm{~m}$ horizons in boxes E1, E2, and F1, cf. Table 1), the median slope is $-0.00129 \mathrm{~mL} \mathrm{~L}^{-1} \mathrm{a}^{-1}(n=21 ; 0.058 \mu \mathrm{M})$, while the median of the significant slopes is $-0.00266 \mathrm{~mL} \mathrm{~L}^{-1} \mathrm{a}^{-1} \mathrm{O}_{2}$ ( $n=13 ; 0.120 \mu \mathrm{M})$. Multiplying the last rate by 40 years, the estimated $\mathrm{O}_{2}$ decrease would equal the median $\mathrm{O}_{2}$ level of $0.11 \mathrm{~mL} \mathrm{~L}^{-1}$ between 200 and $500 \mathrm{~m}$ depth for the same period, which clearly was not the case because of $\mathrm{O}_{2}$ advection. Further, Fig. 4 and Tables 5, 6, and Supplement S.6 imply the disappearance of $\mathrm{O}_{2}$ during the current decades from most of the central Arabian Sea. Regrettably, the STOX probe has outdated this implication, which otherwise would have been sensational. In conclusion, the seasonal and decadal $\mathrm{O}_{2}$ losses at depth appear to be largely replaced by advection, which, however, does not enter the OMZ directly from the south (cf. Sect. 4.1.3).

The same pattern as for the annual regressions of medians holds also for the medians of the within-season slopes on year in the OMZ boxes with $\geq 4$ values each after omitting the 1960s, which weight the regressions perhaps unduly
(Fig. 4, Table 6). Especially noticeable in the table is the number of statistically significant declines in Box D2, off Goa (for further details, see Supplement Sect. 6).

In summary, as with the $\mathrm{O}_{2}$ concentrations, the rates of $\mathrm{O}_{2}$ change over four decades in the central OMZ differ significantly between the two principal seasons, but $\mathrm{O}_{2}$ does decline in both. The faster decreases are observed during the NEM with the higher $\mathrm{O}_{2}$ concentrations, while the reverse holds for the SWM. For the two intermonsoon periods, we have too few data to invite comments. The slopes for the two principal seasons change signs in the north.

\subsection{Nitrite}

The geochemical significance of the Arabian Sea principally rests on the presence or absence of denitrification and formation of $\mathrm{N}_{2}$ (dinitrogen). Our $\mathrm{NO}_{2}^{-}$observations for most depths and boxes extend from 1960-1965 to the beginning of the new century. Because we study this parameter as an indicator of active denitrification, the zero or near-zero values are considered only in passing. Note that once the denitrification threshold is crossed, $\mathrm{NO}_{2}^{-}$is both produced and consumed. The accumulation is determined by several factors including the availability of substrates and the composition of the microbial community (Naqvi, 1991). An important pathway of $\mathrm{NO}_{2}^{-}$consumption can be anammox, which combines $\mathrm{NO}_{2}^{-}$ and $\mathrm{NH}_{4}^{+}$(Dalsgaard et al., 2003, 2005; Kuypers et al., 2003; 
Table 5. Seasonal regressions of $\mathrm{O}_{2}$ on year in OMZ with slopes and medians with $n \geq 5$ ( $p$ of slope: $* \leq 0.20$; ** $\leq 0.10$; *** $\leq 0.05$; $n$ number of values; SE: Standard Error of regression). See Fig. 3 for names and length of seasons.

\begin{tabular}{|c|c|c|c|c|c|c|c|c|}
\hline Box & $\begin{array}{l}\text { Depth } \\
(\mathrm{m})\end{array}$ & Season & Year & $\begin{array}{l}\text { Median } \\
(\mathrm{mL} \\
\left.\mathrm{L}^{-1}\right)\end{array}$ & $\begin{array}{l}\text { Slope } \\
\left(\mathrm{mL} \mathrm{L}^{-1}\right. \\
\left.\mathrm{a}^{-1}\right)\end{array}$ & $p$ & $n$ & SE \\
\hline \multirow[t]{5}{*}{ D1 } & 150 & SWM & 1963-2004 & 0.15 & -0.0017 & 0.70 & 5 & 0.140 \\
\hline & 200 & SWM & 1963-2004 & 0.12 & -0.0019 & $0.19 *$ & 8 & 0.069 \\
\hline & 300 & SWM & 1963-2004 & 0.04 & -0.0025 & 0.25 & 7 & 0.095 \\
\hline & 400 & SWM & 1963-2004 & 0.09 & -0.0005 & 0.57 & 7 & 0.032 \\
\hline & 500 & SWM & 1963-2004 & 0.13 & -0.0008 & 0.42 & 9 & 0.041 \\
\hline \multirow[t]{10}{*}{ F1 } & 150 & NEM & 1977-2002 & 0.32 & -0.0033 & 0.89 & 14 & 0.458 \\
\hline & 200 & NEM & 1988-2002 & 0.15 & -0.0091 & $0.19 *$ & 12 & 0.090 \\
\hline & 300 & NEM & 1988-2002 & 0.10 & -0.0062 & $0.12 *$ & 9 & 0.045 \\
\hline & 400 & NEM & 1988-2002 & 0.13 & -0.0056 & 0.22 & 9 & 0.054 \\
\hline & 500 & NEM & 1988-2002 & 0.12 & -0.0047 & $0.17 *$ & 8 & 0.041 \\
\hline & 150 & SI & 1990-1994 & 0.34 & -0.0338 & 0.40 & 5 & 0.198 \\
\hline & 150 & SWM & 1963-2004 & 0.10 & -0.0001 & 0.99 & 5 & 0.108 \\
\hline & 200 & SWM & 1963-2004 & 0.04 & -0.0009 & 0.69 & 5 & 0.068 \\
\hline & 400 & SWM & 1963-2004 & 0.09 & -0.0020 & $0.05 * *$ & 5 & 0.023 \\
\hline & 500 & SWM & 1963-2004 & 0.09 & -0.0014 & $0.07 * *$ & 6 & 0.021 \\
\hline \multirow[t]{6}{*}{ G1 } & 150 & NEM & 1965-1997 & 0.28 & 0.0086 & 0.29 & 10 & 0.190 \\
\hline & 200 & NEM & 1965-1997 & 0.08 & 0.0015 & 0.73 & 5 & 0.100 \\
\hline & 300 & NEM & 1965-1997 & 0.16 & 0.0044 & 0.43 & 6 & 0.125 \\
\hline & 400 & NEM & 1965-1997 & 0.15 & 0.0014 & 0.61 & 5 & 0.058 \\
\hline & 300 & SI & 1994-2002 & 0.15 & -0.0056 & 0.59 & 5 & 0.095 \\
\hline & 150 & FI & 1963-1988 & 0.28 & -0.0017 & 0.81 & 5 & 0.188 \\
\hline \multirow[t]{10}{*}{ D2 } & 150 & NEM & 1988-1998 & 0.06 & -0.0037 & $0.02 * * *$ & 7 & 0.012 \\
\hline & 200 & NEM & 1988-1998 & 0.08 & -0.0015 & 0.59 & 10 & 0.037 \\
\hline & 300 & NEM & 1988-1998 & 0.08 & -0.0041 & $0.13^{*}$ & 8 & 0.027 \\
\hline & 400 & NEM & 1977-1998 & 0.11 & -0.0036 & $0.07 * *$ & 10 & 0.036 \\
\hline & 500 & NEM & 1977-1998 & 0.15 & -0.0008 & 0.72 & 9 & 0.043 \\
\hline & 150 & SWM & 1963-2004 & 0.07 & -0.0056 & 0.58 & 7 & 0.325 \\
\hline & 200 & SWM & 1963-2004 & 0.04 & -0.0016 & $0.09 * *$ & 9 & 0.035 \\
\hline & 300 & SWM & 1963-2004 & 0.04 & -0.0025 & $0.01 * * *$ & 7 & 0.014 \\
\hline & 400 & SWM & 1963-2004 & 0.06 & -0.0037 & $0.10 * *$ & 8 & 0.063 \\
\hline & 500 & SWM & 1963-2004 & 0.09 & -0.0022 & $0.16^{*}$ & 11 & 0.065 \\
\hline \multirow[t]{2}{*}{ E2 } & 150 & NEM & 1963-1992 & 0.36 & 0.0090 & 0.34 & 5 & 0.063 \\
\hline & 500 & NEM & 1963-1992 & 0.11 & 0.0020 & 0.59 & 5 & 0.079 \\
\hline \multirow[t]{5}{*}{$\mathrm{F} 2$} & 150 & NEM & 1965-1988 & 0.15 & 0.0003 & 0.96 & 7 & 0.209 \\
\hline & 200 & NEM & 1965-1988 & 0.08 & 0.0014 & 0.26 & 6 & 0.029 \\
\hline & 300 & NEM & 1965-1988 & 0.06 & 0.0048 & $0.02 * * *$ & 5 & 0.022 \\
\hline & 400 & NEM & 1965-1988 & 0.06 & 0.0046 & $0.05 * * *$ & 6 & 0.045 \\
\hline & 500 & NEM & 1965-1988 & 0.11 & 0.0038 & $0.01 * * *$ & 8 & 0.029 \\
\hline \multirow[t]{2}{*}{ G2 } & 150 & NEM & 1965-1992 & 0.43 & -0.0200 & 0.21 & 5 & 0.280 \\
\hline & 200 & NEM & 1965-1977 & 0.08 & 0.0090 & $0.12 *$ & 5 & 0.055 \\
\hline
\end{tabular}

for the Arabian Sea see Nicholls et al., 2007, and Jensen et al., 2011).

In the Arabian Sea, denitrification to $\mathrm{N}_{2}$ rather than the anammox route was found by Ward et al. (2009, with earlier references; also Bulow et al., 2010) to be dominant. Lam et al. (2011), in contrast, stressed the anammox pathway lead- ing to $\mathrm{N}_{2}$ losses in OMZs. In this OMZ the highest $\mathrm{NO}_{3}^{-}$ deficit as well as the excess $\mathrm{N}_{2}$ tend to coincide with the $\mathrm{NO}_{2}^{-}$maximum, so the association of $\mathrm{NO}_{2}^{-}$with active denitrification seems hard to argue against. While anammox is an autotrophic process, both $\mathrm{NO}_{2}^{-}$and $\mathrm{NH}_{4}^{+}$are largely derived from the heterotrophic decomposition of organic matter 
Table 6. Medians with slopes and intercepts of seasonal regressions of $\mathrm{O}_{2}$ on year in the $\mathrm{OMZ}$ without 1960 s with $\geq 4$ values during similar periods. $p:{ }^{*} \leq 0.20 ; * * \leq 0.10 ; * * * \leq 0.05 ; n$ number of values; SE Standard Error of regression. See Fig. 3 for names of seasons and months.

\begin{tabular}{|c|c|c|c|c|c|c|c|c|c|}
\hline Box & $\begin{array}{l}\text { Depth } \\
(\mathrm{m})\end{array}$ & Season & Year & $\begin{array}{l}\text { Median } \\
(\mathrm{mL} \\
\left.\mathrm{L}^{-1}\right)\end{array}$ & $\begin{array}{l}\text { Slope } \\
\left(\mathrm{mL} \mathrm{L}^{-1}\right. \\
\left.\mathrm{a}^{-1}\right)\end{array}$ & $p$ & $n$ & $\begin{array}{l}\text { Interc. } \\
(\mathrm{mL} \\
\left.\mathrm{L}^{-1}\right)\end{array}$ & SE \\
\hline \multirow{9}{*}{ D2 } & 200 & NEM & 1988-1998 & 0.08 & -0.0015 & 0.58 & 10 & 3.1 & 0.037 \\
\hline & 200 & SWM & 1987-2004 & 0.03 & -0.0039 & $0.19 *$ & 7 & 7.8 & 0.037 \\
\hline & 300 & NEM & 1988-1998 & 0.08 & -0.0041 & $0.13 *$ & 8 & 8.2 & 0.027 \\
\hline & 300 & SWM & 1987-2004 & 0.04 & -0.0026 & $0.07 * *$ & 6 & 5.2 & 0.015 \\
\hline & 400 & NEM & 1988-1998 & 0.11 & -0.0071 & $0.03 * * *$ & 9 & 14.3 & 0.033 \\
\hline & 400 & SWM & 1986-2004 & 0.05 & -0.0087 & $0.05 * * *$ & 6 & 17.4 & 0.055 \\
\hline & 400 & FI & 1980-1996 & 0.20 & -0.0134 & $0.12 *$ & 4 & 26.9 & 0.069 \\
\hline & 500 & NEM & 1988-1998 & 0.15 & -0.0065 & $0.05 * * *$ & 8 & 13.1 & 0.032 \\
\hline & 500 & SWM & 1986-2004 & 0.09 & -0.0052 & $0.05^{* * *}$ & 8 & 10.5 & 0.037 \\
\hline \multirow[t]{9}{*}{ F1 } & 200 & NEM & 1988-2002 & 0.15 & -0.0091 & $0.19 *$ & 12 & 18.3 & 0.090 \\
\hline & 200 & SI & 1990-1996 & 0.20 & -0.0131 & 0.23 & 4 & 26.4 & 0.040 \\
\hline & 200 & SWM & 1995-2004 & 0.03 & -0.0025 & 0.84 & 4 & 5.0 & 0.083 \\
\hline & 300 & NEM & 1988-2002 & 0.10 & -0.0062 & $0.12 *$ & 9 & 12.4 & 0.045 \\
\hline & 300 & SWM & 1995-2004 & 0.07 & -0.0140 & 0.37 & 4 & 28.1 & 0.092 \\
\hline & 400 & NEM & 1988-2002 & 0.13 & -0.0056 & 0.22 & 9 & 11.2 & 0.054 \\
\hline & 400 & SWM & 1987-2004 & 0.08 & -0.0043 & $0.08 * *$ & 5 & 8.6 & 0.020 \\
\hline & 500 & NEM & 1988-2002 & 0.12 & -0.0047 & $0.17 *$ & 8 & 9.5 & 0.041 \\
\hline & 500 & SWM & 1987-2004 & 0.08 & -0.0019 & 0.45 & 4 & 3.8 & 0.024 \\
\hline G1 & 300 & SI & 1990-1994 & 0.15 & -0.0292 & 0.41 & 4 & 58.3 & 0.098 \\
\hline
\end{tabular}

and are therefore dependent on the supply of the latter. Ward (2013) reviewed new laboratory work showing the importance of the $\mathrm{C}: \mathrm{N}$ ratio of the substrate, so we believe that the debate about which is the dominant path toward $\mathrm{N}_{2}$ in the Arabian Sea may be close to solution.

\subsubsection{Seasonality of nitrite concentrations}

Previous research in the open Arabian Sea had suggested slightly higher $\mathrm{NO}_{2}^{-}$values during the NEM than during the SWM periods (Naqvi et al., 1990; de Sousa et al., 1996). Assuming the $\mathrm{NO}_{2}^{-}$concentration roughly reflects the strength of overall suboxic conditions, a more intense denitrification was inferred for the NEM. In contrast, Morrison et al. (1999) did not find consistent seasonal trends. The occurrences of higher $\mathrm{NO}_{2}^{-}$levels during the NEM suggested here are in line with the cited earlier work.

To avoid possible decadal bias, we compare seasons of similar intervals of years in Fig. 5 as we did with $\mathrm{O}_{2}$. For the observations indicating active denitrification $(>0.5 \mu \mathrm{M})$, Table 7 lists the significant differences between seasons in median $\mathrm{NO}_{2}^{-}$levels within depth ranges and boxes. As for $\mathrm{O}_{2}$, the results may be taken as climatological medians at least for the horizons with more than four or five samples, in contrast to the work by those earlier authors who considered only one or two cruises. Note that we mainly deal with small differences between large numbers. As with $\mathrm{O}_{2}$, the pattern is obscured when viewing the significant (Table 7) and nonsignificant pairs (not shown) together.

\subsubsection{Interannual variability of $\mathrm{NO}_{2}^{-}$}

In order to investigate the longer term (interannual to decadal) changes in the intensity of suboxic conditions, we examined $\mathrm{NO}_{2}^{-}$profiles at the location of GEOSECS sta. 416 $\left(19^{\circ} 45^{\prime} \mathrm{N}, 64^{\circ} 37^{\prime} \mathrm{E}\right.$, occupied in December 1977), visited by us nine times between 1992 and 2004. The site, placed in the southwestern corner of Box F1 (see Fig. 1), is close to the periphery of the suboxic zone, which makes it sensitive to changes in the volume and intensity of the reducing zone. Also it is well away from the continental margins and provides high-quality $\mathrm{NO}_{2}^{-}$data going back to the 1970s. A consistent secular change in $\mathrm{NO}_{2}^{-}$with time is not readily discernible.

The $\mathrm{NO}_{2}^{-}$data exhibit large variability of the thickness of the SNM, ranging from $\sim 150$ to $\sim 500 \mathrm{~m}$, and of the peak concentrations, varying between 0 and $4.6 \mu \mathrm{M}$ (Fig. 6). However, since the observations were made in different seasons it is difficult to distinguish interannual from seasonal changes, or from those caused by smaller scale spatio-temporal variability, which is fairly large in this region as demonstrated by the aforementioned results of the quasi-Lagrangian timeseries study conducted around $21^{\circ} \mathrm{N}, 64^{\circ} \mathrm{E}$ (Sect. 3.1.d; Table 3: SK 121; Supplement Fig. S.3.1) in February 1997. 

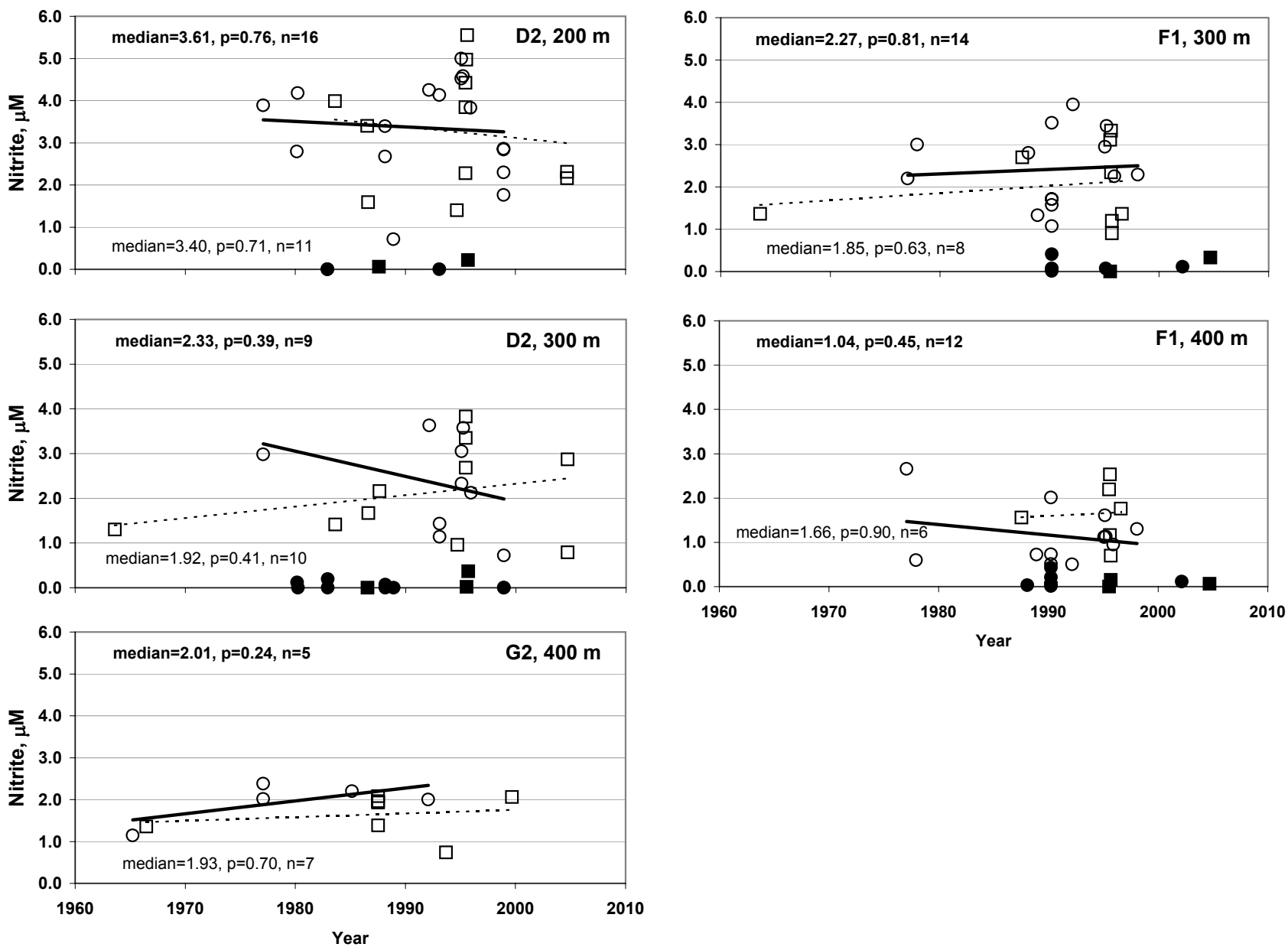

Fig. 5. Examples of regressions of $\geq 0.5 \mu \mathrm{M}$ nitrite on year with data for the NEM (open circles, bold line, and text in upper part of panels) and SWM (open squares, dashed line, and text in lower part of panels) for Boxes D2 (two depths), F1 (two depths), and G2 (one depth), with medians, $p$ for slopes, and number of values (all in Supplement Table S.8, except for D2, $200 \mathrm{~m}$, NEM). The $<0.5 \mu \mathrm{M}$ values (filled symbols) are not part of the regressions.

Nevertheless, it would be reasonable to conclude that interannual changes may be quite substantial as well.

Most of the variability at this site seems to result from advection of PGW, which appears in Supplement Fig. S.3.1 and is a small but significant source of $\mathrm{O}_{2}$ to the OMZ in the northwestern Arabian Sea (Codispoti et al., 2001). In the majority of our data from this location, the PGW salinity maximum was associated with a minimum in $\mathrm{NO}_{2}^{-}$, whereas $\mathrm{NO}_{2}^{-}$ maxima often coincided with the salinity minimum overlying the PGW or just below the latter feature (Fig. 6). Moreover, despite the long period covered, the $\mathrm{NO}_{2}^{-}$and salinity values within the approximate $\sigma_{\mathrm{t}}$ range showed a significant inverse correlation $\left(r^{2}=0.36, p=0.001\right.$ for the slope, $n=26$; Fig. 7). As is to be expected, the variability of salinity is matched with that of temperature (Fig. 8). For example, the most saline PGW core occurring in July 1995 was also the warmest, when the water column did not contain measurable $\mathrm{NO}_{2}^{-}$, indicating the absence of denitrification (Fig. 6).
Thus, while the observations demonstrate remarkable variations in the hydrographic structure and consequently in the redox environment, the changes - probably comprising both seasonal and interannual oscillations - are irregular and do not suggest a secular change in the redox environment over the past quarter-century. That is, the GEOSECS profile (showing some of the most intense reducing conditions recorded in the open Arabian Sea) is quite comparable with the most recent data (sta. AAS42, R/V A. A. Siderenko) collected during the same season (NEM of 2002).

At another site $\left(15^{\circ} \mathrm{N}, 68^{\circ} \mathrm{E}\right.$, located on the eastern limit of Box D2), where reliable $\mathrm{NO}_{2}^{-}$data go back to 1979 (to 1965 if we also include an R/V Atlantis II station at $14.03^{\circ} \mathrm{N}$, $61.14^{\circ} \mathrm{E}$ ) and which falls close to the zone of the most vigorous denitrification, the amplitude of variability (both seasonal and interannual) in $\mathrm{NO}_{2}^{-}$is still quite large. Maximal concentrations observed during 18 visits ranged from 1.16 to $5.31 \mu \mathrm{M}$, while the thickness of the secondary $\mathrm{NO}_{2}^{-}$ 
Table 7. Significant seasonal differences in median $\mathrm{NO}_{2}^{-}$concentrations with $n \geq 2(>0.5 \mu \mathrm{M})$ in the OMZ for boxes and depths during similar periods. One-sided $p$ : with $\geq 2$ values, $* \leq 0.20 ; * * \leq 0.10 ; * * * 0.05$. See Fig. 3 for names of seasons and months.

\begin{tabular}{llllll}
\hline Box & $\begin{array}{l}\text { Depth } \\
(\mathrm{m})\end{array}$ & Years & Seasons & $p$ & $n^{\dagger}$ \\
\hline D1 & 200 & $1995-1996$ & SWM > NEM & $0.20^{*}$ & $(4.84 / 3.44 ; 3 / 5)$ \\
E1 & 300 & $1964-1996$ & SWM > SI & $0.20^{*}$ & $(3.23 / 2.82 ; 3 / 2)$ \\
F1 & 300 & 1990 & NEM > SI & $0.20^{*}$ & $(1.71 / 1.60 ; 5 / 2)$ \\
& 400 & $1990-1996$ & NEM > SI & $0.01^{* * *}$ & $(1.66 / 1.05 ; 10 / 4)$ \\
& 200 & $1983-1995$ & SWM > SI & $0.10^{* *}$ & $(3.90 / 2.24 ; 4 / 4)$ \\
& 200 & $1987-1995$ & SWM > NEM & $0.10^{* *}$ & $(3.90 / 2.10 ; 4 / 8)$ \\
& 400 & $1987-1996$ & SWM > SI & $0.20^{*}$ & $(1.66 / 1.05 ; 6 / 4)$ \\
G1 & 200 & $1983-1995$ & NEM > SI & $0.05^{* * *}$ & $(3.71 / 1.18 ; 5 / 3)$ \\
& 200 & $1960-1995$ & NEM > FI & $0.20^{*}$ & $(3.50 / 1.60 ; 6 / 3)$ \\
& 200 & $1983-1995$ & SWM > SI & $0.10^{* *}$ & $(3.04 / 1.18 ; 2 / 3)$ \\
& 500 & $1960-1995$ & FI > SWM & $0.10^{* *}$ & $(1.30 / 0.78 ; 2 / 4)$ \\
D2 & 150 & $1983-1996$ & FI > SWM & $0.20^{*}$ & $(5.31 / 2.00 ; 3 / 10)$ \\
& 200 & $1960-1995$ & NEM > SI & $0.10^{* *}$ & $(3.36 / 2.58 ; 7 / 3)$ \\
E2 & 200 & $1987-1995$ & NEM > SWM & $0.20^{*}$ & $(3.49 / 2.01 ; 6 / 4)$ \\
& 300 & $1987-1988$ & SWM > NEM & $0.20^{*}$ & $(3.22 / 2.53 ; 2 / 4)$ \\
\hline
\end{tabular}

$\dagger$ Median concentrations and number of values for the two seasons (see first footnote in Table 4).

maximum varied from $<100 \mathrm{~m}$ to $>300 \mathrm{~m}$. Again, a consistent secular change in $\mathrm{NO}_{2}^{-}$with time is not discernible.

\subsubsection{Rates of decadal changes of nitrite}

We show below that more increases than decreases of $\mathrm{NO}_{2}^{-}$ were found on the decadal scale among the regressions for each year in spite of the great variability of the parameter, i.e., denitrification tended to increase, in contrast to the observations from the GEOSECS site (Sect. 4.3.2).

The slopes of $\mathrm{NO}_{2}^{-}$concentrations of $\geq 0.5$ and $\geq 1.5 \mu \mathrm{M}$ on year for boxes and depths in the OMZ vary greatly and without an obvious pattern by either sign or value (Supplement Table S.7; representative plots in Fig. 5). In the two groupings of $\mathrm{NO}_{2}^{-}$levels, positive slopes contribute 21 to a total of 29 in the first and 12 of 24 in the second group, respectively. Thus trends of increases in $\mathrm{NO}_{2}^{-}$were more common than decreases. The distribution between seven positive and five negative significant slopes in Supplement Table S.7 is without any pattern. The ranges (medians) for the positive and negative slopes are 0.0253 to $0.8363(0.0498)$ and -0.0168 to -0.1035 ( -0.0404$) \mu \mathrm{M} \mathrm{a}^{-1}$, respectively. The median increases and decreases correspond to 2.0 and $1.6 \mu \mathrm{M}$ over four decades.

Few trends are obvious among the seasonal regressions on years (Supplement Table S.8). The positive slopes (increases of $\mathrm{NO}_{2}^{-}$) are twice as frequent as the negative ones during the NEM and the SWM periods. Considering Supplement Tables S.7 and S.8 together, there is a suggestion for den- itrification having undergone intensification during the four decades.

To investigate decadal changes of $\mathrm{NO}_{2}^{-}$in the $\mathrm{OMZ}$ in another way, the number of "zero values" (i.e., $\leq 0.2 \mu \mathrm{M}$ ), of $\geq 0.5 \mu \mathrm{M}$, and of $\geq 1.5 \mu \mathrm{M}$, each relative to the total number of $\mathrm{NO}_{2}^{-}$values for a depth and box for 1985 and earlier, are compared with the data acquired since then (see Supplement Sect. 7). The result is that denitrification increased after 1985 also when estimated in this manner.

\section{Implications of the results}

\subsection{Overview}

The introduction into oceanography of the STOX sensor has opened a new era of re-assessing all previous measurements of dissolved $\mathrm{O}_{2}$ in marine and freshwater bodies experiencing water-column $\mathrm{O}_{2}$ depletion. We face the possible overthrow of long-standing results, unless a reasonably accurate conversion ratio for the historic data can be found. The invention of the STOX probe is another example from aquatic sciences of a new technology, rather than concepts, changing the field. Among new concepts in oceanography, however, is the large investment of the last two or three decades into long-term time-series observations without a specific hypothesis, which is so different from the canon of proper scientific conduct of hypothesis-driven original research (cf. Church et al., 2013). 

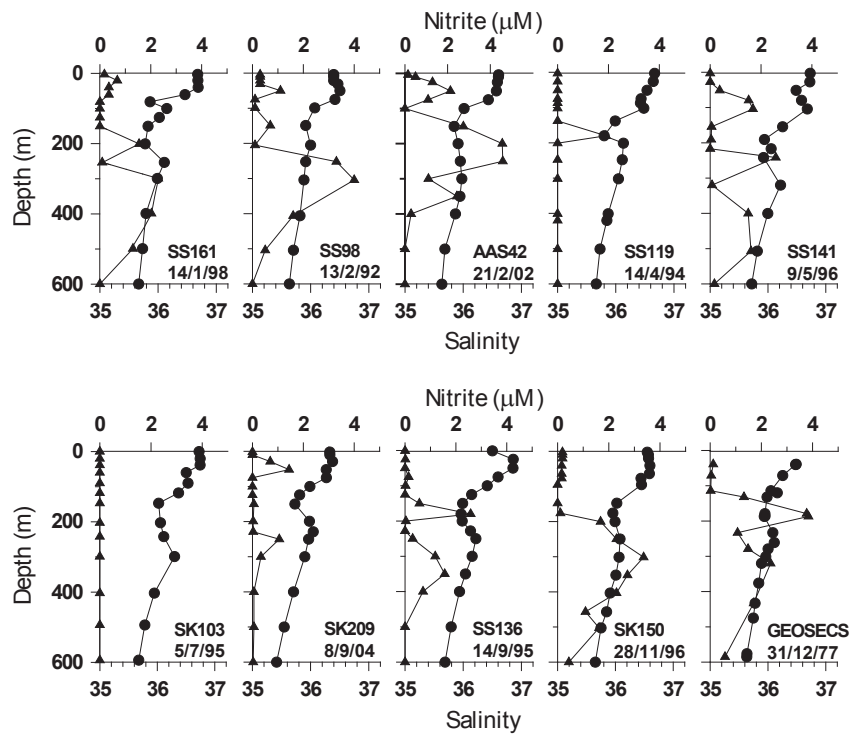

Fig. 6. Nitrite (triangles) and salinity (circles) to $600 \mathrm{~m}$ depth at the site of GEOSECS sta. 416 of 1977, revisited between 1992 and 2004 (panels arranged by month of visit; diamond in Fig. 1 marks the location).

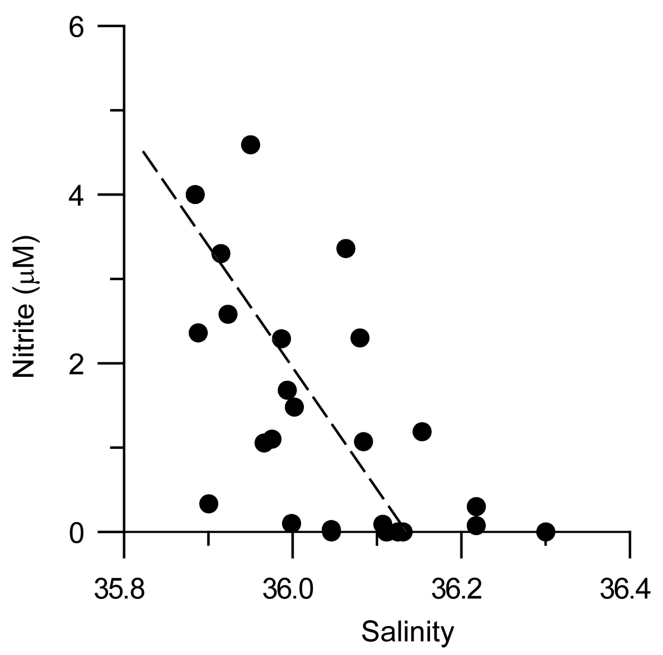

Fig. 7. Nitrite on salinity within and in the vicinity of the Persian Gulf salinity maximum ( $\sigma_{\mathrm{t}}$ range, $26.18-26.74 \mathrm{~kg} \mathrm{~m}^{-3}$ ) during the visits to the GEOSECS site shown in Fig. 6 . The equation for the regression line is $\mathrm{NO}_{2}^{-}=-14.566 \times$ salinity +526.30 .

We have collated historic $\mathrm{O}_{2}$ measurements - that may no longer be considered accurate enough - and $\mathrm{NO}_{2}^{-}$data toward time series, because we do not know of a reason why the temporal trends of $\mathrm{O}_{2}$ would not hold in spite of the large bias shown by the STOX probe. In effect, we assume a bias with small enough variability that will not obliterate trends in $\mathrm{O}_{2}$. Only time will tell whether our assumption was right, but two to three decades are required for a new, STOX-based time series. The regional and temporal coherence and con-

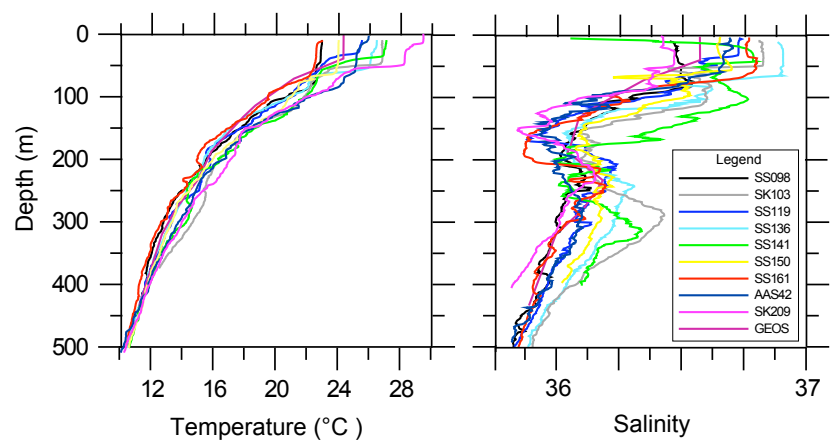

Fig. 8. Temperature and salinity records to $500 \mathrm{~m}$ depth during the visits to the GEOSECS site (for dates, see Fig. 6).

sistencies of the $\mathrm{O}_{2}$ distributions presented here, however, argue for the validity of using these seemingly outdated $\mathrm{O}_{2}$ measurements.

Our $\mathrm{NO}_{2}^{-}$values are not affected by the new nanomolar procedure for nitrite (Garside, 1982), because four-fifths of our samples are far above the lower limit of the traditional analytical method. In contrast, if the one-fifth of the nearzero records in our collation turn out to be too high by comparison with the new method, it would strengthen our point of the patchy occurrence of $\mathrm{O}_{2}$ in the $\mathrm{OMZ}$ as preventing denitrification and supporting metazoan life

The $\mathrm{NO}_{2}^{-}$levels observed since 1933-1934 by every expedition looking for this species suggest that $\mathrm{O}_{2}$ concentrations in the OMZ have been broadly nanomolar at least since that time. The presence of metazoans, however, which was noted at least that long, shows that the OMZ of the Arabian Sea not only was not sulfidic but was not functionally anoxic as stated for the tropical Pacific off South America by Thamdrup et al. (2012). Also, high $\mathrm{NO}_{3}^{-}$concentrations in the water column, proving the absence of free $\mathrm{H}_{2} \mathrm{~S}$, were observed since the beginning of measurement in the late 1950s. Finally, the disconnect of concentrations and temporal trends between salinity and $\mathrm{O}_{2}$ in our meridional swath between the $\mathrm{OMZ}$ and the area adjoining to the south (Boxes A-C; Table 1; Sects. 4.1.3 and 4.2.2; Supplement Sect. S.1) shows that $\mathrm{O}_{2}$ is advected into the $\mathrm{OMZ}$ from the southwest rather than directly from the south (cf. McCreary et al., 2013; Resplandy et al., 2012).

In addition, we describe strong seasonality of $\mathrm{O}_{2}$ between 200 and $500 \mathrm{~m}$ depth with the SWM season showing significantly lower levels than found during the NEM. At $200 \mathrm{~m}$ and possibly at $250 \mathrm{~m}$, the seasonal consumption is principally restored by eddies, while between 300 and $500 \mathrm{~m}$ new $\mathrm{O}_{2}$ is advected horizontally. The $\mathrm{O}_{2}$ loss is probably restored on an annual basis. Also, we observe statistically significant fast declines of $\mathrm{O}_{2}$ between 15 and $20^{\circ} \mathrm{N}$ and increases at 20 and $21^{\circ} \mathrm{N}$. The mean $\mathrm{NO}_{2}^{-}$content in the OMZ probably increased especially after 1985 . 


\subsection{Specific points for future work}

\subsubsection{Oxygen, nitrite, nitrate, and metazoan plankton}

We noted that significant titration-based $\mathrm{O}_{2}$ values and $\mathrm{NO}_{2}^{-}$co-occur temporally. Also, $21 \%$ of 707 discrete OMZ samples analyzed for $\mathrm{O}_{2}$ were without $\mathrm{NO}_{2}^{-}$. Following Thamdrup et al. (2012), these would have contained $\geq 0.002 \mathrm{~mL} \mathrm{~L}^{-1}(\sim 0.1 \mu \mathrm{M}) \mathrm{O}_{2}$, which is well below the detection limit of the conventional $\mathrm{O}_{2}$ methods (the value marks onset of $\mathrm{NO}_{3}^{-}$reduction; see also Sect. 1). In Sect. 3.2.6 and Supplement Sect. S.3, we review that the OMZ of the Arabian Sea with its pronounced secondary $\mathrm{NO}_{2}^{-}$maximum harbors resident metazoan plankton throughout, but the observations all come from net hauls of $\geq 50 \mathrm{~m}$ vertical intervals. Nitrite was usually observed at standard depths, which are vertically widely spaced in the OMZ. It is unknown anywhere in the open sea whether metazooplankton actually co-occurs with $\mathrm{NO}_{2}^{-}$as residents living day and night at $\leq 0.002 \mathrm{~mL} \mathrm{~L}^{-1}$. It would be physiologically extraordinary (cf. Childress and Seibel, 1998).

For tying $\mathrm{NO}_{2}^{-}, \mathrm{O}_{2}$, and metazoan occurrence together, we suggest in future to collect the animals with large water bottles (e.g., the Russian 100 to $140 \mathrm{~L}$ samplers, Vinogradov et al., 1987), from which samples for $\mathrm{NO}_{2}^{-}$are also drawn. While the STOX sensor could measure the actual $\mathrm{O}_{2}$ levels, routine determination of $\mathrm{NO}_{2}^{-}$as a simple indicator of extremely low $\mathrm{O}_{2}$ concentration would provide a limit to the $\mathrm{O}_{2}$ capacity of metazooplankton. Using such bottles, R/V Dimitriy Mendeleyev in a section off Peru at $\sim 15^{\circ} \mathrm{S}$ in mid-March 1978 reported $1-100 \mathrm{mg}$ (a few samples with 100-250) $\mathrm{mg} \mathrm{m}^{-3}$ wet weight of mesozooplankton (calculated from the species counts) at $10 \mathrm{~m}$ vertical intervals to $150 \mathrm{~m}$ depth and at 175 and $200 \mathrm{~m}$, with 3-8 $\mu \mathrm{M} \mathrm{NO}_{2}^{-}$ and $\geq 12 \mu \mathrm{M} \mathrm{NO}_{3}^{-}$at seven deep stations (Bordovskiy et al., 1980: Figs. 14a, b; Semenova et al., 1980: Fig. 10). Because sampling during daylight hours dominated, however, inclusion of biomass of daily migrators is possible. We suggest new nighttime collections, which presumably will catch only resident animals.

\subsubsection{Local time change and $\mathrm{O}_{2}$ consumption rate}

Any time series of $\mathrm{O}_{2}$ in the sea determines the local time change, which is the sum of the $x, y, z$ components of advection and eddy diffusion plus the biological consumption (utilization). For direct measurement of the latter, enclosing of water and following the concentration changes during incubation are necessary, which is quite difficult because of the small rates of change in $\mathrm{OMZ}$ water and bottle effects on the enclosed organisms (for OMZ work, cf. Jayakumar et al., 2009; Stewart et al., 2012). However, knowing and understanding the regional distribution of seasonal change of biological consumption of $\mathrm{O}_{2}$ and its variability is considered by many the Holy Grail of biogeochemistry of the sea.
We know of four computed estimates of $\mathrm{O}_{2}$ consumption rate for OMZs, all made prior to the appearance of STOX and hence using too high $\mathrm{O}_{2}$ concentrations, as we use for assessing local time changes. The two earlier ones by Warren (1994) and Sarma (2002) determined the difference between the annual northward transport and the southward export of $\mathrm{O}_{2}$ across 12 and $10^{\circ} \mathrm{N}$, respectively, into the $\mathrm{OMZ}$ of the Arabian Sea and did not consider vertical or horizontal features. We cite only Warren (1994), who elaborated on a similar model by Olson et al. (1993) and estimated a consumption of $0.10 \mathrm{~mL} \mathrm{~L}^{-1} \mathrm{a}^{-1}$ for the depth interval of 200 $1000 \mathrm{~m}$. He estimated a possible error by about a factor of two. Both Warren and Sarma incorporated the coastal regions with their higher rates and the more intensive north-south water exchange than is to be expected in our meridional, central band. They also included the 500-1000 m depth interval (lower mesopelagic) where the $\mathrm{O}_{2}$ consumption rate is reduced because of the oxidation of organic carbon that sinks through the upper mesopelagic. Thus it would be difficult to guess a value parallel to the 250-300 m interval calculated by Resplandy et al. (2012) for the central Arabian Sea, but both Warren's (1994) and Sarma's (2002) ranges might have been of the order of a few times of $0.01 \mathrm{~mL} \mathrm{~L}^{-1} \mathrm{a}^{-1}$ (a few $\left.10 \mu \mathrm{L} \mathrm{a}^{-1}\right)$.

Stramma et al. (2010) drew up $\mathrm{O}_{2}$ budgets from the supply routes of water in a part of the $\mathrm{OMZ}$ of the eastern $\mathrm{Pa}$ cific $\left(3^{\circ} \mathrm{N}\right.$ to $3^{\circ} \mathrm{S}$, in the west to the date line; $200-700 \mathrm{~m}$ depth). They found a decrease in $\mathrm{O}_{2}$ (total time change) of roughly $0.5 \mu \mathrm{mol} \mathrm{kg} \mathrm{kg}^{-1} \mathrm{a}^{-1}$ and calculated an $\mathrm{O}_{2}$ utilization (consumption) rate of about $4 \mu \mathrm{mol} \mathrm{kg} \mathrm{k}^{-1} \mathrm{a}^{-1}$ (roughly 0.01 and $0.09 \mu \mathrm{LL}^{-1} \mathrm{a}^{-1}$, respectively). As stated in Sect. 3.2.1, Resplandy et al. (2012), in their eddy-resolving model, computed a median $\mathrm{O}_{2}$ utilization rate of $2.8 \mu \mathrm{mol} \mathrm{L} \mathrm{L}^{-1} \mathrm{a}^{-1}$ (0.06 $\left.\mathrm{mL} \mathrm{L}^{-1} \mathrm{a}^{-1}\right)$ for 250-300 $\mathrm{m}$ depth for the central Arabian Sea. The rate declined with depth such that the median at $400 \mathrm{~m}$ was $0.85 \mathrm{~mol} \mathrm{~L}^{-1} \mathrm{a}^{-1}\left(0.04 \mathrm{~mL} \mathrm{~L}^{-1} \mathrm{a}^{-1}\right)$. Thus the estimates of $\mathrm{O}_{2}$ consumption by Stramma et al. (2010) and Resplandy et al. (2012) differ, which may not entirely be due to regional differences in primary production and food webs. Our secular median $\mathrm{O}_{2}$ decline in the central OMZ (200-500 m depth) is only $0.00129 \mathrm{~mL} \mathrm{~L}^{-1} \mathrm{a}^{-1}(0.058 \mu \mathrm{M}$; Sect. 4.2.2). Importantly, Resplandy et al. (2012) reported for the NEM and SWM that the amplitude of seasonal $\mathrm{O}_{2}$ change from vertical eddy-driven advection was several times that from biological consumption (cf. their Fig. 6, CAS region), which is opposite to the result of Stramma et al. We cannot judge whether this gross divergence is due to the hydrographic settings of the two regions or the authors' approaches to the problem but note again that the $\mathrm{O}_{2}$ utilization rate is a key parameter to know.

\subsection{Decadal change of oxygen}

The origin of this paper during the late 1990s was a question about decadal variability in the $\mathrm{OMZ}$, especially of $\mathrm{O}_{2}$, and 
secular change, if any. The coherent south-north differences in the signs of significant slopes of the regressions of $\mathrm{O}_{2}$ on year (Sect. 4.2.2; Supplement Table S.6) suggest an underlying reality, but do the decreases between 15 and $20^{\circ} \mathrm{N}$ (Fig. 4) signify a one-way street toward complete removal of $\mathrm{O}_{2}$ ? A few STOX measurements, especially in Box D2 off Goa, appear as the most promising avenue to the answer, since it is well studied and prone to low $\mathrm{O}_{2}$. Because of the lack of $\mathrm{O}_{2}$ measurements prior to the 1960 s, we cannot rule out the possibility that the decline of $\mathrm{O}_{2}$ in the $\mathrm{OMZ}$ inferred from our data could be a part of a natural cycle.

\subsection{Would global warming expand this OMZ?}

Global change has reached the Arabian Sea. Since about 1960, the North Indian Ocean between about 200 and $500 \mathrm{~m}$ depth has warmed by up to $0.1{ }^{\circ} \mathrm{C}$, most probably due to advection (Barnett et al., 2005). Based on an updated NODC data set (cf. Levitus, 2002), Harrison and Carson (2007: Fig. 6), using essentially the same database as Barnett et al. (2005) for the central open Arabian Sea, found an increase of approximately $0.5^{\circ} \mathrm{C}$ for the period $1950-2000$ at 100 , 300 , and $500 \mathrm{~m}$ depth.

In our view the answer to the question posed by the headline may depend on the one hand on how the extent and intensity of the OMZ, which is presently controlled dominantly by physical processes (i.e., stratification and circulation and associated re-oxygenation by waters at depth advecting across the equator), will be affected by global warming. On the other hand, it is not clear whether the overall $\mathrm{O}_{2}$ distribution in a changed climate would depend more on the rate of $\mathrm{O}_{2}$ consumption (utilization) by particulate and dissolved organic matter (POC, DOC), which is supplied from the euphotic zone by the top-down actions in the food web. Since according to the model of Resplandy et al. (2012) for the OMZ, advection within the basin is several times larger than consumption (see Sect. 4.2.1), should we worry about small biological changes and consumption?

Advected from outside of the model domain is the $\mathrm{O}_{2}$ rich subantarctic mode water of the South Indian Ocean (Sen Gupta and Naqvi, 1984). In a revisited cross section along $32^{\circ} \mathrm{S}$, Bindoff and McDougall (2000) observed an $\mathrm{O}_{2}$ decrease of up to $0.2 \mathrm{~mL} \mathrm{~L}^{-1}$ near $\sigma_{\mathrm{t}}$ of $27.2 \mathrm{~kg} \mathrm{~m}^{-3}$ (see our Fig. 3) between median dates of 1962 and 1987. The authors suggested a slowdown of circulation in the subtropical gyre as the cause, which allowed more time for $\mathrm{O}_{2}$ consumption. Another repeat of the cross section at $32^{\circ} \mathrm{S}$ in 2002 (Bryden et al., 2003), however, showed a reversal of the processes found for the period between the 1960s and 1987, suggesting a speeding up of the circulation of the subtropical gyre. Thus there are signs pointing to variability rather than unidirectional global change, as stated by Bryden et al. (2003) for the region near $32^{\circ} \mathrm{S}$, north of the formation region of the mode water and the $\mathrm{O}_{2}$ source for the upper OMZ in the Arabian Sea (see also Álvarez et al., 2011).
If in contrast in the future consumption is to outrank advection in parts of the Arabian Sea (as presently in the eastern equatorial Pacific, Stramma et al., 2010), then the top-down effects of changes in zooplankton on the fraction of primary production that reaches the OMZ from above will become paramount (see Banse, 2013: p. 15). This major problem is not merely figuratively set on the top of the dependence on possible climate-related changes of circulation of regional, seasonal, and annual primary production.

Global warming will affect the seasons and alter the hydrography, as well as the community compositions, and hence the POC and DOC fluxes into the OMZ. The regime shift near Hawaii, a profound alteration in food web dynamics presumed to be due to quite small physical climate changes (Karl et al., 2001), is the warning by the proverbial writing on the wall: even when the physiological impact on phyto- or zooplankton species of as large an increase of $1{ }^{\circ} \mathrm{C}$ may be negligible, the community changes and ensuing biological impacts resulting from small shifts in the balances between growth and mortality of the major phytoand zooplankton species can at present not be foreseen from environmental information, let alone numerically predicted (for the demands on modeling see, e.g., Prowe et al., 2012). We do not even know the effect(s) on the biochemical processes determining the $\mathrm{O}_{2}$ distribution after an adaptation to the STOX-era $\mathrm{O}_{2}$ concentrations in the extant models.

In conclusion, for judging the impact of global change on the $\mathrm{O}_{2}$ balance in the $\mathrm{OMZ}$ and on its vertical and horizontal extent, predictions of hydrographic changes and of $\mathrm{O}_{2}$ consumption (utilization) must be of a useful accuracy. This may at present be out of reach.

\section{Summary and conclusions}

We looked for changes in the upper OMZ of the central Arabian Sea (150-500 $\mathrm{m}$ depth) within $12-21^{\circ} \mathrm{N}$ latitudes and $64-68^{\circ} \mathrm{E}$ longitudes using all available discrete and acceptable historical $\mathrm{O}_{2}$ data that were collected by the Winkler method with visual endpoint detection between 1959 and 2004. Similarly, we studied the concomitant $\mathrm{NO}_{2}^{-}$determinations, which come from the secondary nitrite maximum (SNM). We discussed additional observations from latitudes $8-10^{\circ} \mathrm{N}$ that were treated in passing. For $\mathrm{O}_{2}$ and $\mathrm{NO}_{2}^{-}$, as well as salinity, we present climatologies.

Within the OMZ, the medians of $\mathrm{O}_{2}$ for four horizons $(200,300,400$ and $500 \mathrm{~m})$ range between 0.04 and $0.15 \mathrm{~mL} \mathrm{~L}^{-1}$ (mean, $0.11 \mathrm{mLL}^{-1}, \sim 5 \mu \mathrm{mol} \mathrm{kg}^{-1}$ ). During the four decades $\mathrm{O}_{2}$ shows significant declines with time between 12 and $20^{\circ} \mathrm{N}$, but an opposite, increasing trend near $21^{\circ} \mathrm{N}$. There is significant seasonality, with higher values occurring during the NE monsoon and spring inter-monsoon as compared to the SW monsoon season. Close to the upper boundary of the OMZ near 150-200 (or 250?) m depth, diapycnal re-supply of $\mathrm{O}_{2}$ appears to be important but at 
$300-500 \mathrm{~m}$ most of the presumably annual re-oxygenation is through isopycnal inputs from the northern quadrant.

An unknown but probably substantial uncertainty in our analysis comes from the error associated with titrimetric $\mathrm{O}_{2}$ measurements on which almost all of the historical data are based, as evident from the two orders-of-magnitude lower concentrations determined by the recently developed STOX sensor within oceanic OMZs.

Our data on $\mathrm{NO}_{2}^{-}$, which only appears within OMZs when the dissolved $\mathrm{O}_{2}$ is $\leq 0.05 \mu \mathrm{mol} \mathrm{kg}{ }^{-1}\left(\sim 0.001 \mathrm{mLL}^{-1}\right)$, do not show clear seasonal or secular patterns. We cannot state unequivocally whether or not the OMZ of the Arabian Sea has intensified in recent decades.

The spatial and temporal variability at drift stations is high and seasonal change of hydrography is marked even at $500 \mathrm{~m}$. Therefore, assumption of a steady state for the upper OMZ will not be valid, and any estimates of elemental budgets or rates of biogeochemical transformations must not be based on a single cruise or data for only one season.

We make three recommendations for future work. First, an observation system to monitor key hydrographic and biogeochemical variables at high temporal and spatial resolutions must be put in place in this biogeochemically and ecologically important oceanic region. For detecting secular change, parts of the systems have to be laid out for the long term (many decades).

Also, greater application of the STOX sensor is certain to change our views about all oceanic OMZs, including the Arabian Sea. But as $\mathrm{NO}_{2}^{-}$can be analyzed far more easily and with great precision, it should be used as a proxy for identification and mapping of functionally anoxic waters.

Thirdly, in $79 \%$ of our 707 OMZ samples with $>0.02 \mu \mathrm{MNO}_{2}^{-}, \quad \mathrm{O}_{2}$ must have been $\leq 0.05 \mu \mathrm{mol} \mathrm{kg}-1$ $\left(\sim 0.001 \mathrm{mLL}^{-1}\right)$, rather than our $\mathrm{OMZ}$ mean $\mathrm{O}_{2}$ of $\sim 0.01 \mathrm{mLL}^{-1}$. These samples largely represent the SNM. Live copepods, however, are collected with fine nets towed in the SNM. Do animals actually co-occur with elevated $\mathrm{NO}_{2}^{-}$, or have the nets fished in water of the $21 \%$ samples without $\mathrm{NO}_{2}^{-}$, which are interspersed in the SNM? To clarify whether there is resident metazoan life at such extraordinarily low $\mathrm{O}_{2}$ levels, we suggest sampling of meso-zooplankton with 100 liter bottles, from which $\mathrm{NO}_{2}^{-}$can routinely be drawn as substitutes for elaborate STOX measurements.

\section{Supplementary material related to this article is available online at http://www.biogeosciences.net/11/ 2237/2014/bg-11-2237-2014-supplement.pdf.}

Acknowledgements. First of all we are indebted to the many anonymous colleagues who collected the samples, analyzed them in their laboratories, and largely deposited the results in data centers. For additional observations we thank D. B. Olson and the late F. A. Schott, as well as J. Hermann. S. R. Emerson and A. Körtzinger and two anonymous reviewers made useful suggestions to the text. J. Pierson and H. Hadaway helped with the designs of some figures. S. Tipple arranged all the tables. And there was the empathy by Copernicus' staff. K. Banse and J. R. Postel also wish to acknowledge the partial support by the US Office of Naval Research, grants no. N00014-97-1-0120 and N00014-04-1-0142. The service charge was financed by K. Banse's TIAA/CREF account.

Edited by: R. Hood

\section{References}

Álvarez, M., Tanhua, T., Brix, H., Lo Monaco, C., Metzl, N., McDonagh, E. L., and Bryden, H. L.: Decadal biogeochemical changes in the subtropical Indian Ocean associated with Subantarctic Mode Water, J. Geophys. Res., 116, C09016, doi:10.1029/2010JC006475, 2011.

Anon.: Protocols for the Joint Global Ocean Flux Study (JGOFS) core measurements. Manual and Guides, 29, Intergov. Oceanogr. Comm./ Sci. Comm. Oceanic Res., UNESCO, Paris, 170 pp. 1994.

Artamonov, Yu. V.: The circulation and structure of water masses of the Arabian Sea based on synoptic surveys, in: The Mesoscale Structure of the Epipelagic Ecosystem of the Open Northern Arabian Sea, edited by: Banse, K. and Piontkovski, S. A., 12-46, Universities Press (India), Hyderabad, 2006.

Bange, H. W., Naqvi, S. W. A., and Codispoti, L. A.: The nitrogen cycle in the Arabian Sea, Progr. Oceanogr., 65, 145-158, 2005.

Banse, K.: Reflections about chance in my career, and on the top-down regulated world, Annu. Rev. Mar. Sci., 5, 1-19, doi:10.1146/annurev-marine-121211-172359, 2013.

Banse, K. and Postel, J. R.: Wintertime convection and ventilation of the upper pycnocline in the northernmost Arabian Sea, Indian Ocean Biogeochemical Processes and Ecological Variability, Geophys. Monogr. Ser., 185, 87-117, doi:10.1029/2008GM000704, 2009.

Banse, K. and Postel, J. R.: The southern border of the upper $\mathrm{O}_{2}$ minimum in the central Arabian Sea during 1994 and 1995, in preparation, 2015.

Barnett, T. P., Pierce, D. W., Achuta Rao, K. M., Gleckler, P. J., Santer, B. D., Gregory, J. M., and Washington, W. M.: Penetration of human-induced warming into the world's ocean, Science, 309, 284-287, 2005.

Beal, L. M., Chereskin, T. K., Bryden, H. L., and Ffield, A.: Variable water properties, heat and salt fluxes in the Arabian Sea, between the onset and wane of the 1995 southwest monsoon, Deep-Sea Res. Pt. II, 50, 2049-2075, 2003.

Bendschneider, K. and Robinson, R. J.: A new spectrophometric method for the determination of nitrite in seawater, J. Mar. Res., 11, 87-96, 1952.

Bianchi, D., Dunne, J. P., Sarmiento, J. L., and Galbraith, E. D.: Data-based estimates of suboxia, denitrification, and $\mathrm{N}_{2} \mathrm{O}$ production in the ocean and their sensitivities 
to dissolved $\mathrm{O}_{2}$, Global Biogeochem. Cy., 26, GB2009, doi:10.1029/2011GB004209, 2012.

Bindoff, N. L. and McDougall, T. J.: Decadal changes along an Indian Ocean section at $32^{\circ} \mathrm{S}$ and their interpretation, J. Phys. Oceanogr., 30, 1207-1222, 2000.

Bobko, N. I., and Rodionova, N. Yu.: Distribution of dissolved oxygen and biogenic elements in the northwestern Arabian Sea during February-March 1990, in: The Mesoscale Structure of the Epipelagic Ecosystem of the Open Northern Arabian Sea, edited by: Banse, K. and Piontkovski, S. A., 54-64, Universities Press (India), Hyderabad, 2006.

Bordovskiy, O. K., Gusarova, A. N., Vintovkin, V. P., Sokolova, I. A., and Stunzhas, P. A.: Hydrochemical characteristics of the ecosystem, in: Ecosystems of the Pelagial off Peru, edited by: Vinogradov, M. E., 29-49, Nauka, Moscow, 1980 (in Russian).

Böttger-Schnack, R.: Vertical structure of small metazoan plankton, especially non-calanoid copepods, I: Deep Arabian Sea, J. Plankt. Res., 18, 1073-1101, 1996.

Bryden, H. L., McDonagh, E. L., and King, B. A.: Changes in ocean water mass properties: Oscillations or trends?, Science, 300, 2086-2088, 2003.

Bulow, S. E., Rich, J. J., Naik, H. S., Pratihary, A. K., and Ward, B. B.: Denitrification exceeds anammox as a nitrogen loss pathway in the Arabian Sea oxygen minimum zone, Deep-Sea Res. Pt. I, 57, 384-393, doi:10.1016/j.dsr.2009.10.014, 2010.

Butler, M., Bollens, S. M., Burkhalter, B., Madin, L. P., and Horgan, E.: Mesopelagic fishes of the Arabian Sea: distribution, abundance and diet of Chauliodus pammelas, Chauliodus sloani, Stomias affinis, and Stomias nebulosus, Deep-Sea Res. Pt. II, 48, 1369-1383, 2001.

Chang, B. X., Devol, A. H., and Emerson, S. R.: Fixed nitrogen loss from the eastern tropical North Pacific and Arabian Sea oxygen deficient zones determined from measurements of $\mathrm{N}_{2}$ :Ar, Glob. Biogeochem. Cy., 26, GB3030, doi:10.1029/2011GB004207, 2012.

Chereskin, T. K., Wilson, W. D., and Beal, L. M.: The Ekman temperature and salt fluxes at $8^{\circ} 30^{\prime} \mathrm{N}$ in the Arabian Sea during the 1995 southwest monsoon, Deep-Sea Res. Pt. II, 49, 1211-1230, 2002.

Childress, J. J. and Seibel, B. A.: Life at stable low oxygen levels: adaptations of animals to oceanic oxygen minimum layers, J. Exp. Biol., 201, 1223-1232, 1998.

Church, M. J., Lomas, M. W., and Muller-Karger, F.: Sea change: charting the course for biogeochemical ocean time-series research in a new millennium, Deep-Sea Res. Pt. II, 93, 2-15, doi:10.1016/j.dsr2.2013.01.035, 2013.

Codispoti, L. A., Brandes, J. A., Christensen, J. P., Devol, A. H., Naqvi, S. W. A., Paerl, H. W., and Yoshinari, T.: The oceanic fixed nitrogen and nitrous oxide budgets: Moving targets as we enter the anthropocene?, Sci. Mar., 65, 85-105, 2001.

Colborn, J. G.: The thermal structure of the Indian Ocean, International Indian Ocean Expedition Oceanogr. Monogr., 2, Univ. Press of Hawaii, Honolulu, 1975.

Cowie, G. L. and Levin, L. A.: Benthic biological and biogeochemical patterns and processes across an oxygen minimum zone (Pakistan margin, NE Arabian Sea), Deep-Sea Res. Pt. II, 56, 261270, doi:10.1016/j.dsr2.2008.10.001, 2009.

Dalsgaard T., Canfield, T. E., Petersen, J., Thamdrup, B., and Gonzales, J. A.: $\mathrm{N}_{2}$ production by the anammox reaction in the anoxic water column of Golfo Dulce, Costa Rica, Nature, 422 , 606-608, 2003.

Dalsgaard T., Thamdrup, B., and Canfield, D. E.: Anaerobic ammonium oxidation (anammox) in the marine environment, Res. Microbiol., 156, 457-464, 2005.

de Sousa, S. N., Kumar, M. D., Sardessai, S., Sarma, V. V. S. S., and Shirodkar, P. V.: Seasonal variability in oxygen and nutrients in the central and eastern Arabian Sea, Current Sci., 71, 847-851, 1996.

Devol, A. H., Uhlenhopp, A. G., Naqvi, S. W. A., Brandes, J. A., Jayakumar, D. A., Naik, H., Gaurin, S., Codispoti, L. A., and Yoshinari, T.: Denitrification rates and excess nitrogen gas concentrations in the Arabian Sea oxygen deficient zone, Deep-Sea Res. Pt. I, 53, 1533-1547, doi:10.1016/j.dsr.2006.07.005, 2006.

Fabian, H., Koppelmann, R., and Weikert, H.: Full-depths zooplankton composition at two deep sites in the western and central Arabian Sea, Indian J. Mar. Sci., 34, 174-187, 2005.

Fischer, A. S., Weller, R. A., Rudnick, D. L., Eriksen, C. C., Lee, C. M., Brink, K. H., Fox, C. A., and Leben, R. R.: Mesoscale eddies, coastal upwelling, and the upper-ocean heat budget in the Arabian Sea, Deep-Sea Res. Pt. II, 49, 2231-2264, 2002.

Flagg, C. N. and Kim, H.-S.: Upper ocean currents in the northern Arabian Sea from shipboard ADCP measurements collected during the 1994-1996 U.S. JGOFS and ONR programs, Deep-Sea Res. Pt. II, 45, 1917-1959, 1998.

Garside, C.: A chemiluminescent technique for the determination of nanomolar concentrations of nitrate, nitrite, or nitrite alone in seawater, Mar. Chem., 11, 159-167, 1982.

Gilson, H. C.: The nitrogen cycle, Sci. Repts. John Murray Exp. 1933-34, 2, 21-81, 1937.

Hamner, W. M., Madin, L. P., Alldredge, A. L., Gilmer, R. W., and Hamner, P. O.: Underwater observations of gelatinous zooplankton: Sampling problems, feeding biology, and behavior, Limnol. Oceanogr., 20, 907-917, 1975.

Harrison, D. E. and Carson, M.: Is the World Ocean warming? Upper-ocean temperature trends: 1950-2000, J. Phys. Oceanogr., 37, 174-187, doi:10.1175/JPO3005.1, 2007.

Ignatyev, S. M.: Macrozooplankton in the Arabian Sea, in: The Mesoscale Structure of the Epipelagic Ecosystem of the Open Northern Arabian Sea, edited by: Banse, K. and Piontkovski, S. A., 151-161, Universities Press (India), Hyderabad, 2006.

Jayakumar, A., O’Mullan, G. D., Naqvi, S. W. A., and Ward, B. B.: Denitrifying bacterial community composition changes associated with stages of denitrification in oxygen minimum zones, Microb. Ecol., 58, 350-362, doi:10.1007/s00248-009-9487-y, 2009.

Jensen, M. M., Lam, P., Revsbech, N. P., Nagel, B., Gaye, B., Jetten, M. S. M., and Kuypers, M. M. M.: Intensive nitrogen loss over the Omani Shelf due to anammox coupled with dissimilatory nitrite reduction to ammonium, Intern. Soc. Microb. Ecol. J., 5, 1660-1670, doi:10.1038/ismej.2011.44, 2011.

Karl, D. M., Bidigare, R. R., and Letelier, R. M.: Long-term changes in plankton community structure and productivity in the North Pacific Subtropical Gyre: the domain shift hypothesis, Deep-Sea Res. Pt. II, 48, 1449-1470, doi:10.1016/S0967-0645(00)001491,2001

Kim, H.-S., Flagg, C. N., and Howden, S. D.: Northern Arabian Sea variability from TOPEX/Poseidon altimetry data: an extension of the US JGOFS/ONR shipboard ADCP study, Deep-Sea Res. Pt. II, 48, 1069-1096, 2001. 
Kuypers, M. M. M., Slickers, A. O., Lavik, G., Schmid, M., Jørgensen, B. B., Kuenen, J. G., Damsté, J. S. S., Strous, M., and Jetten, M. S. M.: Anaerobic ammonium oxidation by anammox bacteria in the Black Sea, Nature, 422, 608-611, 2003.

Lam, P., Jensen, M. M., Kock, A., Lettmann, K. A., Plancherel, Y., Lavik, G., Bange, H. W., and Kuypers, M. M. M.: Origin and fate of the secondary nitrite maximum in the Arabian Sea, Biogeosciences, 8, 1565-1577, doi:10.5194/bg-8-1565-2011, 2011.

Levitus, S. (Ed.): World Ocean Database 2001, in: NOAA Atlas NESDIS, 42-48, Nat. Oceanogr. Data Center, Ocean Climate Lab., Silver Springs, Maryland, 2002.

Lomas, M. W. and Lipschultz, F.: Forming the primary nitrite maximum: Nitrifiers or phytoplankton?, Limnol. Oceanogr., 51, 2453-2467, 2006.

Madhupratap, M., Gopalakrishnan, T. C., Haridas, P., and Nair, K. K. C.: Mesozooplankton biomass, composition and distribution in the Arabian Sea during the Fall Intermonsoon: implications of oxygen gradients, Deep-Sea Res. Pt. II, 48, 1345-1368, 2001.

Mantoura, F. R. C., Law, C. S., Owens, N. J. P., Burkill, P. H., Malcolm, E., Woodward, S., Howland, R. J. M., and Llewellyn, C. A.: Nitrogen biogeochemical cycling in the northwestern Indian Ocean, Deep-Sea Res. Pt. II, 40, 651-671, 1993.

Maucha, R.: Hydrochemische Methoden in der Limnologie, Die Binnengewässer, 12, Schweizerbarth, Stuttgart, 173 pp., 1932.

McCreary Jr., J. P., Yu, Z., Hood, R. R., Vinaychandran, P. N., Furue, R., Ishida, A., and Richard, K. J.: Dynamics of the IndianOcean oxygen minimum zones, Progr. Oceanogr., 112-113, 1537, doi:10.1016/j.pocean.2013.03.002, 2013.

Mincks, S. L., Bollens, S. M., Madin, L. P., Horgan, E., Butler, M., Kremer, P. M., and Craddock, J. E.: Distribution, abundance, and feeding ecology of decapods in the Arabian Sea, with implications for vertical flux, Deep-Sea Res. Pt. II, 47, 1475-1516, 2000.

Molinari, R. L., Festa, J. F., and Swallow, J. C.: Mixed layer and thermocline depth climatologies in the Western Indian Ocean, NOAA Technical Memorandum ERL AOML-64, 40 pp., 1986.

Morrison, J. M., Codispoti, L. A., Gaurin, S., Jones, B., Manghnani, V., and Zheng, Z.: Seasonal variation of hydrographic and nutrient fields during the US JGOFS Arabian Sea Process Study, Deep-Sea Res. Pt. II, 45, 2053-2101, 1998.

Morrison, J. M., Codispoti, L. A., Smith, S. L., Wishner, K., Flagg, C., Gardner, W. D., Gaurin, S., Naqvi, S. W. A., Manghnani, V., Prosperie, L., and Gundersen, J. S.: The oxygen minimum zone in the Arabian Sea during 1995, Deep-Sea Res. Pt. II, 46, 19031931, 1999.

Murray, C. N., Riley, J. P., and Wilson, T. R. S.: The solubility of oxygen in the Winkler reagents used for the determination of dissolved oxygen, Deep-Sea Res., 15, 237-238, 1968.

Naqvi, S. W. A.: Some aspects of the oxygen-deficient conditions and denitrification in the Arabian Sea, J. Mar. Res., 45, 10401072, 1987.

Naqvi, S. W. A. and Noronha, R. J., Nitrous oxide in the Arabian Sea, Deep-Sea Res., 38, 871-890, 1991.

Naqvi, S. W. A. and Sen Gupta, R.: "NO", a useful tool for the estimation of nitrate deficits in the Arabian Sea, Deep-Sea Res., 32, 665-674, 1985.

Naqvi, S. W. A., Noronha, R. J., Somasundar, K., and Sen Gupta, R.: Seasonal changes in the denitrification regime of the Arabian Sea, Deep-Sea Res., 37, 593-611, 1990.
Naqvi, S. W. A., Kumar, M. D, Narvekar, P. V., de Sousa, S. N., George, M. D., and D'Silva, C.: An intermediate nepheloid layer associated with high microbial metabolic rates and denitrification in the northwest Indian Ocean, J. Geophys. Res., 98, 1646916479, 1993.

Naqvi, S. W. A., Sarma, V. V. S. S., and Jayakumar, D. A.: Carbon cycling in the northern Arabian Sea during the northeast monsoon: Significance of salps, Mar. Ecol.-Prog. Ser., 226, 35-44, 2002.

Naqvi, S. W. A., Bange, H. W., Gibb, S. W., Goyet, C., Hatton, A. D., and Upstill-Goddard, R. C.: Biogeochemical oceanatmosphere transfers in the Arabian Sea, Progr. Oceanogr., 65, 116-144, 2005.

Naqvi, S. W A., Naik, H, Jayakumar, D. A., Shailaja, M. S., and Narvekar, P. V.: Seasonal oxygen deficiency over the western continental shelf of India, in: Past and Present Water Column Anoxia, edited by: Neretin, L. N., 195-224, NATO Science Ser., IV, 64, Springer, Dordrecht (The Netherlands), 2006.

Naqvi, W. A.: Geographical extent of denitrification in the Arabian Sea in relation to some physical processes, Oceanol. Acta, 14, 281-290, 1991.

Nicholls, J. C., Davies, C. A., and Trimmer, M., High-resolution profiles and nitrogen isotope tracing reveal a dominant source of nitrous oxide and multiple pathways of nitrogen gas formation in the central Arabian Sea, Limnol. Oceanogr., 52, 156-168, 2007.

Olson, D. B., Hitchcock, G. L., Fine, R. A., and Warren, B. A.: Maintenance of the low-oxygen layer in the central Arabian Sea, Deep-Sea Res. Pt. II, 40, 673-685, 1993.

Prakash, S., Balakrishnan Nair, T. M., Udaya Bhaskar, T. V. S., Prakash, P., and Gilbert, D.: Oxycline variability in the central Arabian Sea: An Argo-oxygen study, J. Sea Res., 71, 1-8, doi:10.1016/j.seares.2012.03.003, 2012.

Prasanna Kumar, S., Ramaiah, N., Mangesh Gauns, Sarma, V. V. S. S., Muraleedharan, P. M., Raghukumar, S., Dileep Kumar, M., and Madhupratap, M.: Physical forcing of biological productivity in the Northern Arabian Sea during the Northeast Monsoon, Deep-Sea Res. Pt. II, 48, 1115-1126, 2001.

Prowe, A. E. F., Pahlow, M., Dutkiewicz, S., Follows, M., and Oschlies, A.: Top-down control of marine phytoplankton diversity in a global ecosystem model, Progr. Oceanogr., 101, 1-13, doi:10.1016/j.pocean.2011.11.016, 2012.

Ramaswamy, V. and Gaye, B.: Regional variations in the fluxes of foraminifera carbonate, coccolithophorid carbonate and biogenic opal in the northern Indian Ocean, Deep-Sea Res. Pt. I, 53, 271 293, 2006.

Ramesh, K. V. and Krishnan, R.: Coupling of mixed layer processes and thermocline variations in the Arabian Sea, J. Geophys. Res. 110, C05005, doi:10.1029/2004JC002515, 2005.

Ramesh Babu, V., Gangadhara Rao, L. V., and Varadachari, V. V. R.: Sea temperature variations in the northeastern Arabian Sea in relation to the southwest monsoon, in: Monsoon Dynamics, edited by: Lighthill, J. and Pearce, R. P., 481-540, Cambridge University Press, 1981.

Rao, R. R.: The observed variability of the cooling and deepening of the mixed layer in the central Arabian Sea during Monsoon-77, Mausam, 38, 43-48, 1987.

Resplandy, L., Lévy, M., Madec, G., Pous, S., Aumont, O., and Kumar, D.: Contribution of mesoscale processes to nutrient 
budgets in the Arabian Sea, J. Geophys. Res., 116, C11007, doi:10.1029/2011JC007006, 2011.

Resplandy, L., Lévy, M., Bopp, L., Echevin, V., Pous, S., Sarma, V. V. S. S., and Kumar, D.: Controlling factors of the oxygen balance in the Arabian Sea's OMZ, Biogeosciences, 9, 50955109, doi:10.5194/bg-9-5095-2012, 2012.

Revsbech, N. P., Larsen, L. H., Gundersen, J., Dalsgaard, T., Ulloa, O., and Thamdrup, B.: Determination of ultra-low oxygen concentrations in oxygen minimum zones by the STOX sensor, Limnol. Oceanogr. Methods, 7, 371-381, 2009.

Saltzman, J. and Wishner, K. F.: Zooplankton ecology in the eastern tropical Pacific oxygen minimum zone above a seamount, I. General trends, Deep-Sea Res. Pt. I, 44, 907-930, 1997.

Sarma, V. V. S. S.: An evaluation of physical and biogeochemical processes regulating perennial suboxic conditions in the water column of the Arabian Sea, Global Biogeochem. Cy., 16, 1082, doi:10.1029/2001GB001461, 2002.

Semenova, T. N.: Distribution of zooplankton in the southern part of the Peruvian upwelling, in: Ecosystems of the Pelagial off Peru, edited by: Vinogradov, M. E., 145-158, Nauka, Moscow, 1980 (in Russian).

Sen Gupta, R. and Naqvi, S. W. A.: Chemical oceanography of the Indian Ocean, north of the equator, Deep-Sea Res., 31, 671-706, 1984.

Sen Gupta, R., Rajagopal, M. D., and Qasim, S. Z.: Relationship between dissolved oxygen and nutrients in the north-western Indian Ocean, Indian J. Mar. Sci., 5, 201-211, 1976.

Shankar, D., Vinayachandran, P. N., and Unnikrishnan, A. S.: The monsoon currents in the north Indian Ocean, Progr. Oceanogr., 52, 63-120, 2002.

Silva, N., Rojas, N., and Fedele, A.: Water masses in the Humboldt Current System: properties, distribution, and the nitrate deficit as a chemical water mass tracer for Equatorial Surface Water off Chile, Deep-Sea Res. Pt. II, 56, 1004-1020, 2009.

Staubwasser, M., Sirocko, F., Grootes, P. M., and Erlenkeuser, H.: South asian monsoon climate change and radiocarbon in the Arabian Sea during early and middle Holocene, Paleoceanography, 17, 1063, doi:10.1029/2000PA000608, 2002.

Stewart, F. J., Dalsgaard, T., Young, C. R., Thamdrup, B., Revsbech, N. P., Ulloa, O., Canfield, D. E., and DeLong, E. F.: Experimental incubations elicit profound changes in community transcription in OMZ bacterioplankton, PloS One, 7, e37118, doi:10.1371/journal.pone.0037118, 2012.

Stramma, L., Brandt, P., Schott, F., Quadfasel, D., and Fischer, J.: Winter and summer monsoon water mass, heat and freshwater transport changes in the Arabian Sea near $8^{\circ} \mathrm{N}$, Deep-Sea Res. Pt. II, 49, 1173-1195, 2002.

Stramma, L., Johnson, G. C., Firing, E., and Schmidtko, S.: Eastern Pacific oxygen minimum zones: Supply paths and multidecadal changes, J. Geophys. Res., 115, C09011, doi:10.1029/2009JC005976, 2010.

Thamban, M., Kawahata, H., and Purnachandra Rao, V.: Indian summer monsoon variability during the Holocene as recorded in sediments of the Arabian Sea: timing and implications, J. Oceanogr., 63, 1009-1020, 2007.

Thamdrup, B., Dalsgaard, T., and Revsbech, N. P.: Widespread functional anoxia in the oxygen minimum zone of the Eastern South Pacific, Deep-Sea Res. Pt. I, 65, 36-45, doi:10.1016/j.dsr.2012.03.001, 2012.
Ulloa, O., Canfield, D. E., DeLong, E. F., Letelier, R. M., and Stewart, F. J.: Microbial oceanography of anoxic oxygen minimum zones, P. Acad. Natl. Sci., 109, 15996-16003, doi:10.1073/pnas.1205009109, 2012.

Vinogradov, M. E.: Vertical distribution of the oceanic zooplankton, Moscow: Nauka, 318 pp., 1968 (in Russian; Engl. transl. by Israel Progr. Scient. Transl., Jerusalem, 1970, 339 pp.).

Vinogradov, M. E. and Voronina, N. M.: Influence of the oxygen deficit on the distribution of plankton in the Arabian Sea, DeepSea Res., 9, 523-530, 1962 (transl. of the Russian original in Okeanologiya, 1, 1961).

Vinogradov, M. E., Shushkina, E. A., Gorbunov, A. Y., and Shashkov, N. L.: Vertical distribution of the macro- and mesoplankton in the region of the Costa Rica Dome, Oceanology, 31, 559-565, 1991 (Russian original in Okeanologiya, 31, 1990).

Vinogradov, M. Ye., Flint, M. V., Shushkina, E. A., Tutubalin, V. N., and Uger, Ye. G.: Comparative catch efficiency of large-volume sampling bottles and vertical-catch plankton nets, Oceanology, 27, 242-247, 1987.

von Rad, U., Schaaf, M., Michels, K. H., Schultz, H., Berger, W. H., and Sirocko, F.: A 5000-yr record of climate change in varved sediments from the oxygen minimum zone off Pakistan, northeastern Arabian Sea, Quaternary Res., 51, 39-53, 1999.

Ward, B. B.: How nitrogen is lost, Science, 341, 352-353, doi:10.1126/science.1240314, 2013.

Ward, B. B., Devol, A. H., Rich, J. J., Chang, B. X., Bulow, S. E., Naik, H., Pratihary, A., and Jayakumar, A.: Denitrification as the dominant nitrogen loss process in the Arabian Sea, Nature, 461, 78-81, doi:10.1038/nature08276, 2009.

Warren, B. A.: Transindian hydrographic section at Lat. $18^{\circ} \mathrm{S}$ : Property distributions and circulation in the South Indian Ocean, Deep-Sea Res., 28, 759-788, 1981.

Warren, B. A.: Context of the suboxic layer in the Arabian Sea, Proc. Indian Acad. Sci. (Earth Planet. Sci.), 103, 301-314, 1994.

Weller, R. A., Fischer, A. S., Rudnick, D. L., Eriksen, C. C., Dickey, T. D., Marra, J., Fox, C., and Leben, R.: Moored observations of upper-ocean response to the monsoons in the Arabian Sea during 1994-1995, Deep-Sea Res. Pt. II, 49, 2195-2230, 2002.

Wiggert, J. D., Hood, R. R., Banse, K., and Kindle, J. C.: Monsoondriven biogeochemical processes in the Arabian Sea, Progr. Oceanogr., 65, 176-213, doi:10.1016/j.pocean.2005.03.008, 2005.

Wishner, K. F., Gowing, M. M., and Gelfman, C.: Mesozooplankton biomass in the upper $1000 \mathrm{~m}$ in the Arabian Sea: overall seasonal and geographic patterns, and relationship to oxygen gradients, Deep-Sea Res. Pt. II, 45, 2405-2432, 1998.

Wishner, K. F., Gelfman, C., Gowing, M. M., Outram, D. M., Rapien, M., and Williams, R. L.: Vertical zonation and distributions of calanoid copepods through the lower oxycline of the Arabian Sea oxygen minimum zone, Progr. Oceanogr., 78, 163 191, doi:10.1016/j.pocean.2008.03.001, 2008.

Wong, G. T. F.: Removal of nitrite interference in the Winkler determination of dissolved oxygen, Mar. Chem., 130-131, 28-32, doi:10.1016/j.marchem.2011.11.003, 2011.

Wyrtki, K.: Oceanographic Atlas of the International Indian Ocean Expedition, National Science Foundation, Washington DC, 529 pp., 1971. 